\title{
Making sense of Arab labor markets: the enduring legacy of dualism
}

Ragui Assaad

Correspondence: assaad@umn.edu Humphrey School of Public Affairs, University of Minnesota,

Minneapolis, MN 55455, USA
Abstract: It is well-established that Arab labor markets share certain common characteristics, including an oversized public sector, high youth unemployment, weak private sectors, rapidly growing but highly distorted educational attainment, and low and stagnant female labor force participation. I argue in this paper that all of these features can be explained by the deep and persistent dualism that characterizes Arab labor markets that resulted from the use of labor markets by Arab regimes as tool of political appeasement in the context of "authoritarian bargain" social contracts. Even as fiscal crises have long destabilized these arrangements in most non-oil Arab countries, culminating in the dramatic political upheavals of the Arab Spring, I argue that the enduring legacy of dualism will continue to strongly shape the production and deployment of human capital in Arab economies for some time.

JEL classification: 125, J21, J24, J31, J45, O53, P52

Keywords: Labor market dualism; Arab Spring; Unemployment; Education; Authoritarian bargain

\section{Introduction}

The stylized facts about the structure and operation of Arab labor markets are fairly well established. Much of the Arab World is characterized by an oversized public sector, with employment in the bureaucracy and security forces not only constituting a large fraction of total employment but also a dominant share of formal sector employment (cf. Shaban et al. 2001, Said 2001, World Bank 2004a). It is also well-established that public employment constitutes an important share of employment for politically significant groups in much of the Arab World, such as the educated middle class, citizens of oil-rich monarchies, and members of key sects, tribes or ethnic groups. The oversized public sector has generally meant that the formal private sector is typically anemic and small, relying mostly on government welfare and rent-seeking for its survival (Malik and Awadallah 2013, World Bank 2013a, ESCWA 2012). A corollary of this lack of private sector dynamism has been the growth of informality, especially in situations where the ability of the public sector to continue growing its workforce became increasingly curtailed due to fiscal realities.

Arab economies are also characterized by large, but distorted investments in human capital. While many Arab countries have experienced some of the most rapid increases in educational attainment in the world over the past three decades, much of the investment in human capital has been in pursuit of the credentials useful to access public sector jobs rather than the skills demanded by globalizing economies (Salehi-Isfahani

(C) 2014 Assaad; licensee Springer. This is an open access article distributed under the terms of the Creative Commons Attribution License (http://creativecommons.org/licenses/by/2.0), which permits unrestricted use, distribution, and reproduction in any medium, provided the original work is properly cited. 
2012). The low quality of the human capital produced is clearly manifested in the very low scores obtained by Arab students in standardized international tests (Muliss et al. 2008). With rapidly increasing educational attainment and falling gender gaps in education, one would have expected female labor force participation rates to have risen sharply, given the strong positive relationship between education and participation. This has in fact not happened. Overall female participation rates have stagnated, and, participation rates for educated women have in fact fallen significantly in recent years as opportunities in the public sector have been curtailed. Finally, the best known stylized fact about Arab labor markets is very high youth unemployment. Youth unemployment rates in the Arab region, which are the highest across all major world regions, are clearly associated with the difficulty educated young people have been having in accessing employment for the first time.

The principal argument I advance in this paper is that most of these stylized facts can be explained by one underlying characteristic of Arab labor markets, and that is the deep and persistent dualism that has characterized them throughout the postindependence period. This dualism is primarily driven by the use of public sector employment by authoritarian regimes as a tool to appease politically salient groups as part of the "authoritarian bargain" social contracts they have struck with their citizens. In brief, the authoritarian bargain is a sort of implicit deal between authoritarian regimes and politically significant groups to provide them with well-compensated jobs in the bureaucracy and the security forces, among other privileges such as access to subsidized commodities, housing and services, in exchange for political quiescence, if not loyalty (See Amin et al. 2012; Desai et al. 2009). By using labor markets as means to distribute rents and to buy political quiescence, Arab governments have essentially undermined the labor markets' primary function, which is to efficiently allocate human capital to its most productive uses and to signal the kind of human capital investments that are needed.

The politically significant groups that have benefited from the authoritarian bargain vary from country to country, but include the educated middle classes in many of the populous countries of the region (Algeria, Egypt, Morocco, Tunisia), all citizens in the sparsely populated oil-rich gulf monarchies that depend on large numbers of expatriate workers, and members of important sects, tribes or clans in countries such as Jordan, Iraq, Libya, Syria, and Yemen.

Although these authoritarian bargains often placed unsustainable fiscal burdens on state budgets, they endured in the region as a result of the regimes' continued access to hydrocarbon and other mineral rents, either directly or through foreign aid. Ali and Elbadawi (2012) argue that ruling elites in oil-rich countries attempt to avert revolt by using labor markets as a mechanism to transfer a fraction of the oil rent to politically significant groups. This is done primarily through public sector employment, which tends to be much larger in these countries than comparable developing countries. Their ability to do this is clearly a function of the size of the oil rent per capita that is at their disposal (See also Robinson et al. 2006).

With downward pressure on oil prices in the second half of the 1980s and much of the 1990s, these authoritarian bargain social contracts eventually became fiscally unsustainable and came under severe pressure in a number of countries, especially the more populous oil producers, which had to increasingly resort to repression to maintain the 
political status quo (Soliman 2011, Ali and Elbadawi 2012). As oil prices recovered in the 2000s, there were clear attempts to re-establish the old bargains, with the greatest success in doing so in the oil-rich economies of the Gulf and in places like Algeria in North Africa (Lowi 2009). The regimes without ready access to plentiful mineral rents were forced to gradually renege on their side of the bargain but, besides resorting to greater repression, they tried to minimize the political fallout by protecting insiders and shifting the cost of adjustment to outsiders. Insiders were typically members of the privileged groups who had already gained access to the benefits of the authoritarian bargain in the form of public sector jobs and other entitlements. An important group of outsiders, who bore the brunt of the adjustment, were the young people who invested in the sorts of credentials that would in the past have guaranteed them a place in the bureaucracy, but now found themselves relegated to low-quality informal jobs. Almost all entitlement reforms, including the curtailment of public sector employment, have sought to make the reforms more politically palatable by grandfathering in those who had already acquired the entitlement. Thus existing government workers were for the most part able to retain their jobs and their access to subsidized housing and services, with young newcomers bearing the brunt of the changes (Amin et al. 2012).

While it is hard to formally test the proposition that politically motivated public sector hiring caused all the labor market outcomes I discuss here, I present a great deal of circumstantial evidence in favor of it. I do attempt in the last section of the paper a formal test of the proposition that high public sector employment at the governorate or province level drives young people to queue for government jobs and thus raises youth unemployment. However, this test has obvious limitations in that it essentially assumes that young people's employment prospects and search activities are mostly limited to their local labor market. This assumption is clearly problematic especially for more educated groups who are likely to consider opportunities on a national rather than a regional scale. However, the test does suggest that for less educated youth and even for educated female youth, who may be more geographically constrained, higher levels of youth unemployment are in fact associated with higher local rates of government employment in most of the countries I consider.

In what follows I will first present a simple theoretical model illustrating how public sector hiring and compensation leads to labor market dualism and unemployment. I then present further evidence supporting the stylized facts discussed above and end with an empirical analysis, using census microdata from a number of Arab countries, which links high youth unemployment to the possibility of getting government jobs.

\section{Government hiring and compensation practices, labor market dualism and structural unemployment: a simple model ${ }^{1}$}

The gist of my argument is that the labor market dualism that resulted from the authoritarian bargain and its aftermath continues to drive labor market expectations, choices regarding what type of human capital to invest in, and the queuing behavior that leads to excessive unemployment among new entrants. To illustrate this argument, I will draw on a simple model derived from the classic Harris-Todaro model of migration and unemployment in a dualistic developing economy (Harris and Todaro 1970). The model relies on the public sector paying compensations (including non-wage 


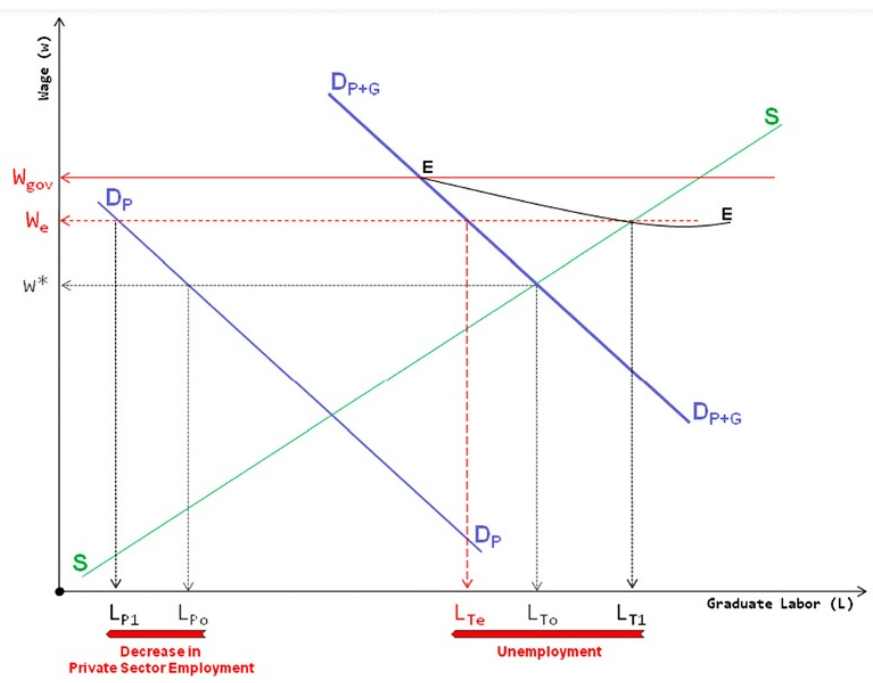

Figure 1 Supply and Demand of Educated Labor in the Presence of a Public Sector Wage Floor. Source: Assaad 1997.

benefits and non-pecuniary aspects of jobs) that are higher than market clearing wages for certain eligible groups. These groups are then induced to queue for the rationed government jobs, with the extent of queuing being a function of the probability of obtaining such a job. If eligibility is based on obtaining a minimum threshold of education, the persistence of this dualism over a long period of time will not only result in high unemployment among educated new entrants, but also the systematic misallocation of human capital to less productive uses in the public sector and to distortions in the sorts of human capital investments people make. The latter problem has been referred to as the "credentialist equilibirum", whereby the lure of public sector employment leads to investments in the acquisition of the diplomas needed to obtain such jobs, at the expense of the skills needed in a competitive private sector-led economy (Salehi-Isfahani 2012).

The simple static supply and demand model of the labor market for graduates eligible for government jobs, shown in Figure 1 illustrates the gist of the argument. The model shows the demand curve for labor in the private sector as $D_{P}$ and the demand curve in both the private and public sectors as $\mathrm{D}_{\mathrm{P}+\mathrm{G}}$. In a competitive labor market, the market clearing wage would be $\mathrm{W}^{*}$. However, the government pays a compensation level $\mathrm{W}_{\text {gov }}$ that is higher than the market clearing wage. This induces new entrants to queue for the rationed government jobs on the basis of an expected wage $\mathrm{W}_{\mathrm{e}}$, which is equal to the probability of getting a job in the government times the government wage $\mathrm{W}_{\text {gov }}$ plus the probability of getting a job in the private sector times the market clearing wage $\mathrm{W}^{*}$. This translates into a labor supply that extends along the parabola E-E from the intersection of the demand curve $\mathrm{D}_{\mathrm{P}+\mathrm{G}}$ and $\mathrm{W}_{\text {gov }}$ to the supply curve $\mathrm{S}$, forming a new equilibrium wage $\mathrm{W}_{\mathrm{e}}$. At that wage, labor supply $\mathrm{L}_{\mathrm{T} 1}$ exceeds labor demand $\mathrm{L}_{\mathrm{Te}}$ and the difference shows up as unemployment of graduates.

A couple of things to note about the results of such a model is that the distortion introduced by the government wage being higher than market clearing wage raises the labor supply of graduates over what it would be otherwise (mostly by inducing more 
people to acquire the credentials that make them eligible for government jobs) and reduces the quantity of labor demanded in the private sector from $L_{P 0}$ to $L_{P 1}$. Thus, this simple static model explains a number of the stylized features of Arab labor markets, namely high unemployment among graduates, strong preference for government jobs among new entrants and propensity to queue for it, excessive demand for credentials, and anemic employment growth in the private sector.

It is of course possible that instead of remaining unemployed while queuing or searching for government jobs, young people enter into informal employment while continuing to search for government employment. A similar extension to the HarrisTodaro model was introduced by Fields (1975). While such behavior is possible, it may not happen right away for all new entrants seeking government jobs, and may not be an option at all for some youth. Young men for instance may want to remain unemployment for some time in order to maximize their search effectiveness and because informal employment may yield lower wages than their initially high reservation wages, which will eventually adjust downward. Young women seeking government employment, on the other hand, are likely to remain in the unemployment state longer than young men because of their poorer informal employment prospects, the reputational risks that such employment could represent for them, and their even higher reservation wages.

\section{An oversized public sector}

The first and most obvious consequence of the use of public employment as a tool for political appeasement is an over-sized public sector. Evidence of an oversized public sector relative to the size of the economy in most Arab countries is not hard to come by. Data from the World Bank on a sample of 12 MENA countries, shown in Figure 2, shows that central government wage and salary expenditures average about 10 percent of GDP, which is higher than in any other world region, including OECD countries (World Bank, no date). On the basis of a smaller sample of 6 MENA countries, the same source shows that the share of general government expenditures on wages and salaries is about 12 percent, similar to the average for OECD countries, but higher than any other developing world region (Ibid.).

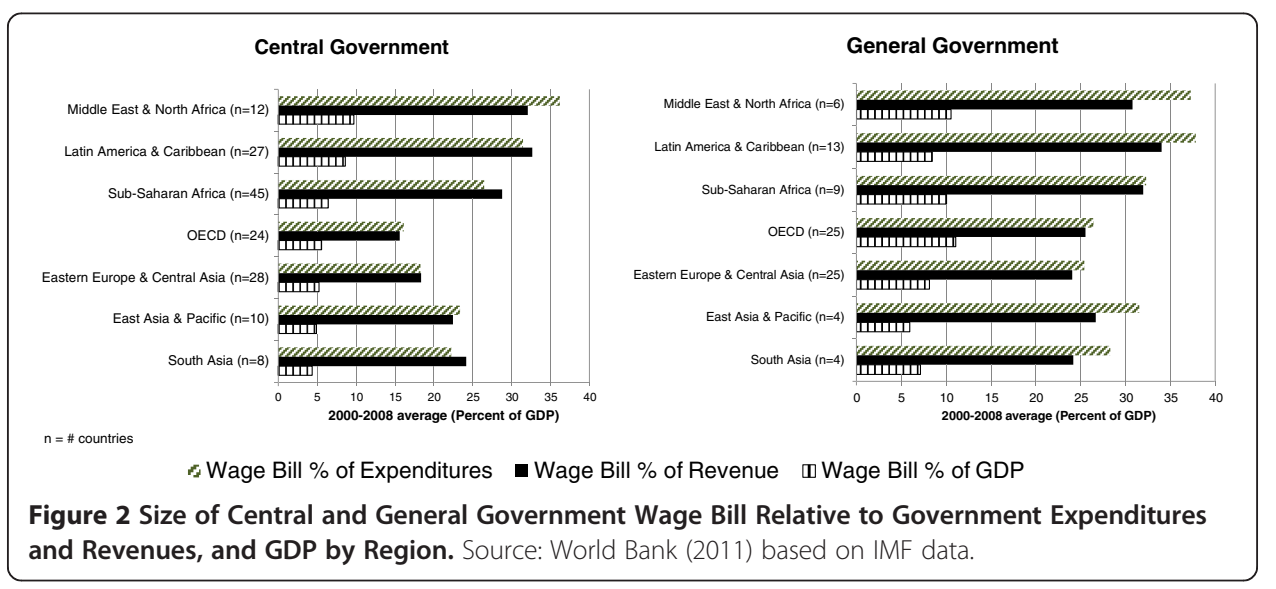


Similarly, Figure 3 shows that public sector employment shares in individual MENA countries are significantly higher than in a sample of comparable developing countries, and also vary significantly within the region, ranging from 14 percent in Morocco to 40 percent in Jordan. In some cases these figures understate the true size of employment in government because they exclude employment in the armed forces, as is known to be the case in Egypt and Syria. The employment shares shown in Figure 3 for Gulf economies strongly understate the contribution of public sector employment to the employment of nationals since they include both nationals and expatriate workers. The share of the public sector in the employment of nationals is as high as $87 \%$ in Qatar, $86 \%$ in Kuwait and 72\% in Saudi Arabia (Baldwin-Edwards 2011). It is in excess of 90\% among UAE nationals (World Bank 2013a).

Evidence on public-private wage differentials in Arab countries is hard to come by. The comparison is complicated by the fact that the public and private sector workforces differ along productive characteristics such as education and experience and that public sector jobs generally offer superior non-pecuniary aspects of employment, such as job security, health benefits, paid vacations, sick leave, etc.. Results using 1988 and 1998 data on Egypt showed that there was a positive differential in wages of about 20 percent favoring the private sector male workers when compared to workers with similar characteristics in the government (Assaad 1997 and Said 2009). The differential for female workers, on the other hand, clearly favored government workers over private sector workers (by 60 percent in 1988 and 10 percent in 1998). Using 2006 data, Said (2009) finds that the differential in favor of the private sector had practically disappeared for males and that favoring government workers for females had widened to 33 percent. When comparing public enterprise to private sector wages, wage differential correcting for education and experience are always in favor of the public sector for both males and females. Said (2009) estimates that they were as high as 27 percent for males and 33 percent for females in 2006. Said (2013) provides similar estimates for Jordan in 2010. She estimates that public sector wages are lower than private sector wages by about 8 percent for males, but higher by 17 percent for females. Given that the non-pecuniary aspects of employment are likely to be substantially higher in the public sector, these public-private wage differentials indicate that total public sector

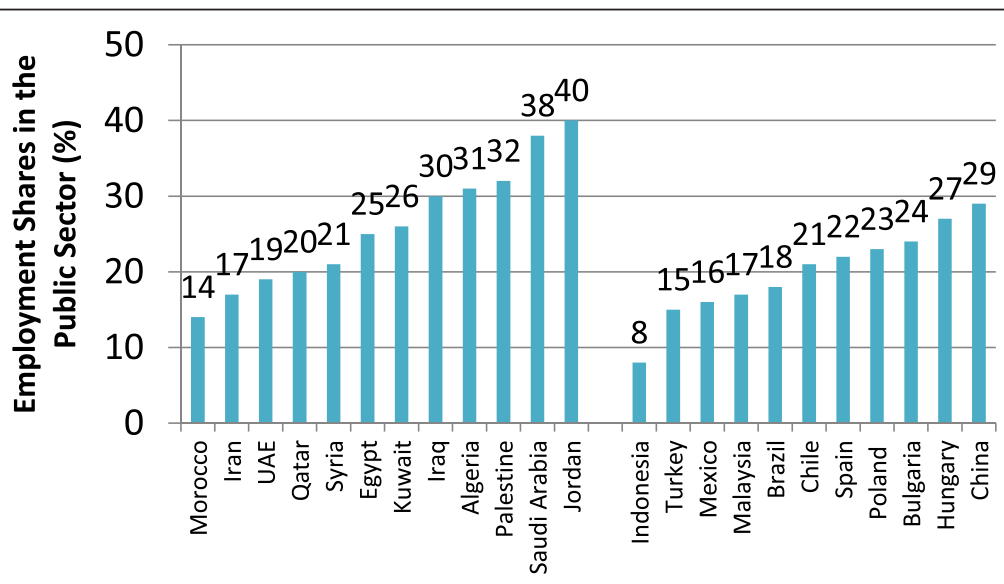

Figure 3 Employment shares in the public sector (\%), averages in the 2000s. Source: World Bank, 2013a. 
compensation significantly exceeds that in the private sector for workers with similar characteristics in both Jordan and Egypt ${ }^{2}$. Although no direct evidence is readily available, it is likely that compensation differentials in favor of the public sector are even larger in oil-rich Arab countries where public employment is used as a primary mechanism to distribute the oil rent.

Given the significant differential in compensation in favor of the public sector, it is no wonder that both youth and adults in the MENA region express strong preference for public sector employment in opinion surveys. When asked whether they prefer employment in government, private business, self-employment, or employment in nonprofit organization, assuming that pay and work conditions were similar, a majority of youth and adults interviewed in the Gallup World Poll in most Arab countries select government employment. As shown in Figure 4, the proportion of youth selecting government employment over the other three options exceeds 50 percent in all countries except for Lebanon, Sudan, Morocco and Algeria. The first three of these countries have some of the lowest public employment rates in the region. Preferences for the public sector tend to be strongest in oil-rich countries, such as UAE, Iraq, and Kuwait, which have traditional used public employment as mechanism to redistribute oil rents, but they are also strong in Yemen, Egypt, and Jordan, which have long traditions of employment graduates in the public sector.

\section{Large but distorted investments in education}

Arab countries have made very significant investments aimed at raising educational attainment and closing the gender gap in education in recent years. As shown in Figure 5, among the 20 countries with the largest increases in educational attainment from 1980 to 2010, as measured by mean years of schooling, eight were Arab countries and the ninth was Iran, which shares many of same economic features.

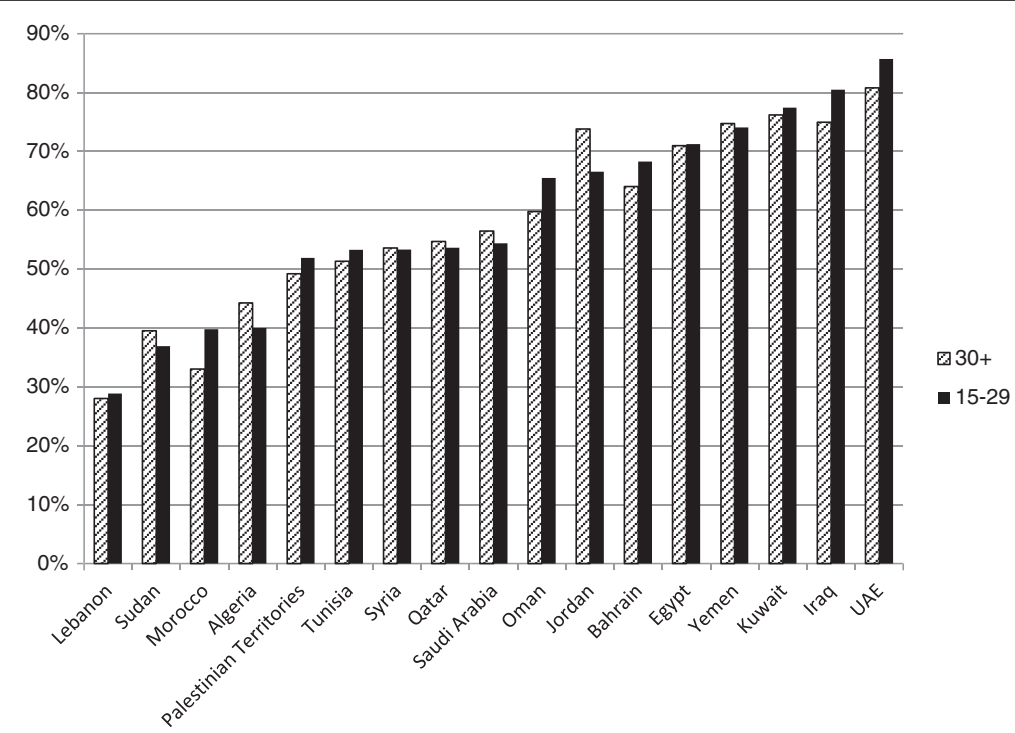

Figure 4 Proportion of Youth (15-29) and Adults (30+) Expressing a Preference for Government Employment if Pay and Work Conditions were Similar, 2011. Source: Gallup (2012). 


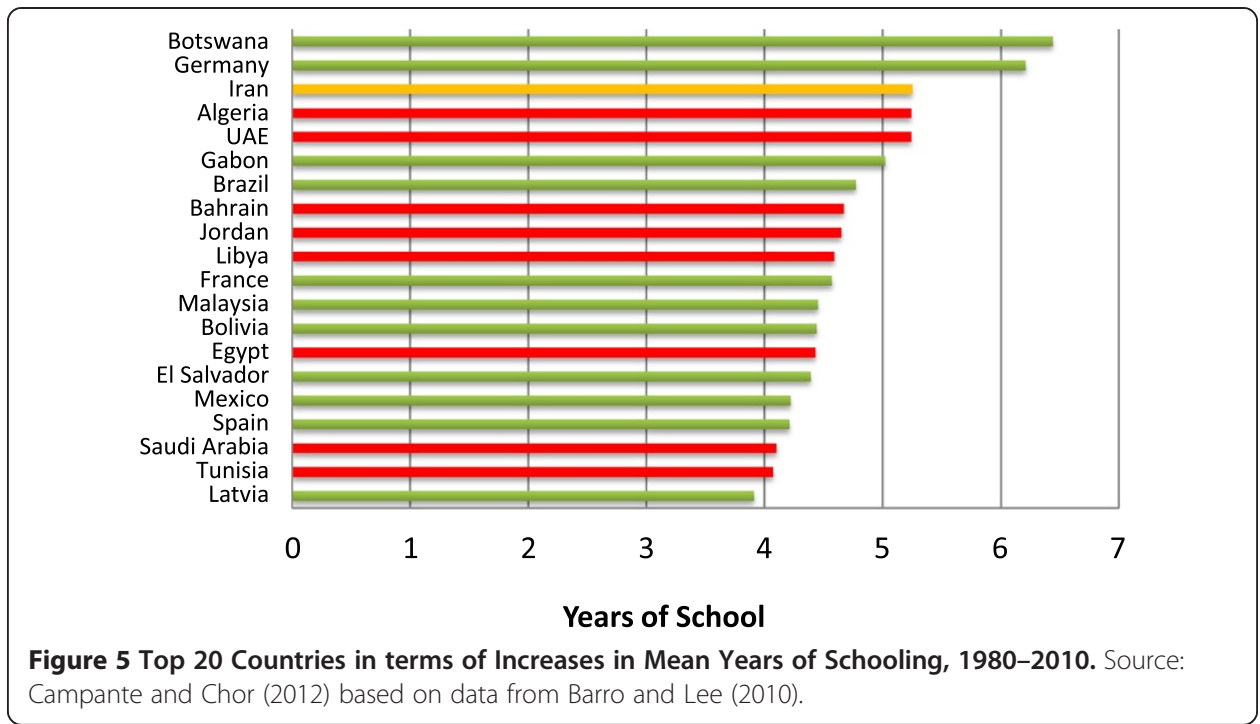

Despite these rapid increases in educational attainment in the Arab world, the quality of education has been persistently low, as evidenced by performance on international tests. As shown in Figure 6, the percentage of $8^{\text {th }}$ graders performing at below the low benchmark in the TIMSS 2007 mathematics achievement tests in MENA is 54 percent, more than twice the international median. Less than 20 percent of eighth graders in the region perform at the "intermediate" benchmark or higher. Fifteen of the 49 countries that participated in the eighth grade mathematics test had fewer than 50 percent of their students attain the "low" benchmark. Of those fifteen countries, ten were Arab countries (See

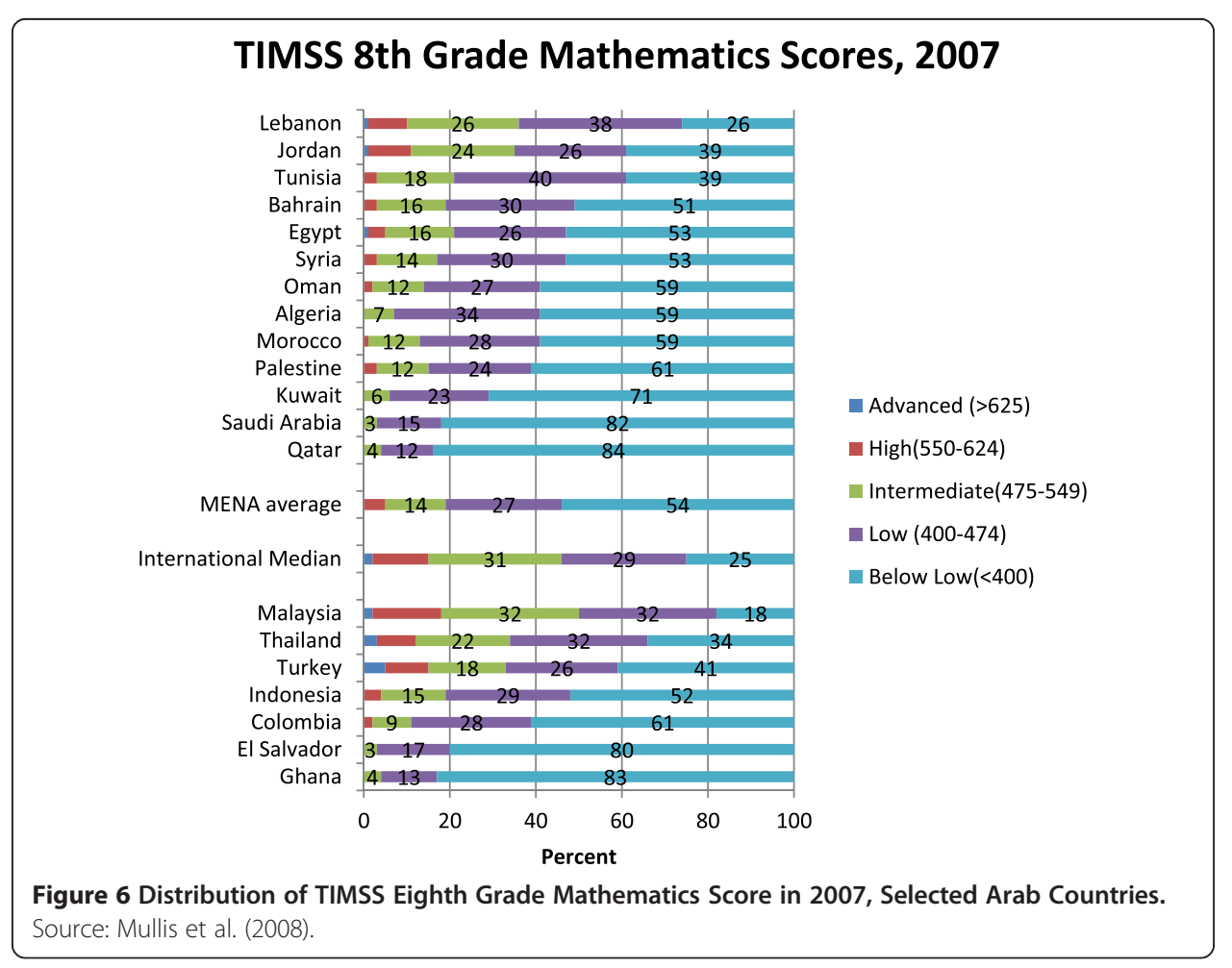


Muliss et al. 2008, p. 71). On the whole, the MENA average performance was slightly worse than that of Indonesia, and significantly worse than that of Thailand and Turkey.

Some of the worst performing countries are among the richest countries in the region, with Qatar, for example, having 84 percent of its children performing under the "low" threshold and Saudi Arabia with 82 percent performing below that level (Figure 6). Eight grade students in both these countries performed worse than those in El-Salvador and about the same as those in Ghana, a much poorer country and the worst performing nonArab country among the TIMSS 2007 participating countries. This suggests that the issue is not lack of resources but the lack of incentives for children to perform well. With guaranteed jobs in the public sector waiting for them, there is no reason for children in these rich countries to exert themselves. Another issue may be the nature of curricula in these countries and the excessive focus on rote memorization.

The large increases in the quantity of education have not generally translated into improved employment prospects for graduates. The frustration of young people who acquired schooling but were not able to reap the requisite economic benefits from it is often cited as one of the main causes of the Arab Spring uprisings (Campante and Chor 2012). To illustrate the dramatic change in employment prospects for secondary school and university graduates over the past three decades, I use two unique data sets to trace the type of first job they were able to obtain over time in both Egypt and Jordan ${ }^{3}$. As shown in Figure 7, over 60 percent of those with secondary degrees or above in Egypt got jobs in the public sector in the 1970s as compared to 20 percent who obtained formal private wage work. The proportion getting public sector employment falls precipitously thereafter in Egypt to reach under 20 percent for those entering in the first half of the 2000s. Nevertheless, the proportion obtaining formal private sector work has hardly changed over the same period. The slack has been taken up by informal private wage work and to a lesser extent unpaid work in family-owned enterprises. There is therefore evidence that educated young people unable to obtain public sector employment will eventually make their way to informal employment, with the hope to eventually exit from it. However, as Assaad (2014, p. 18) demonstrates, by

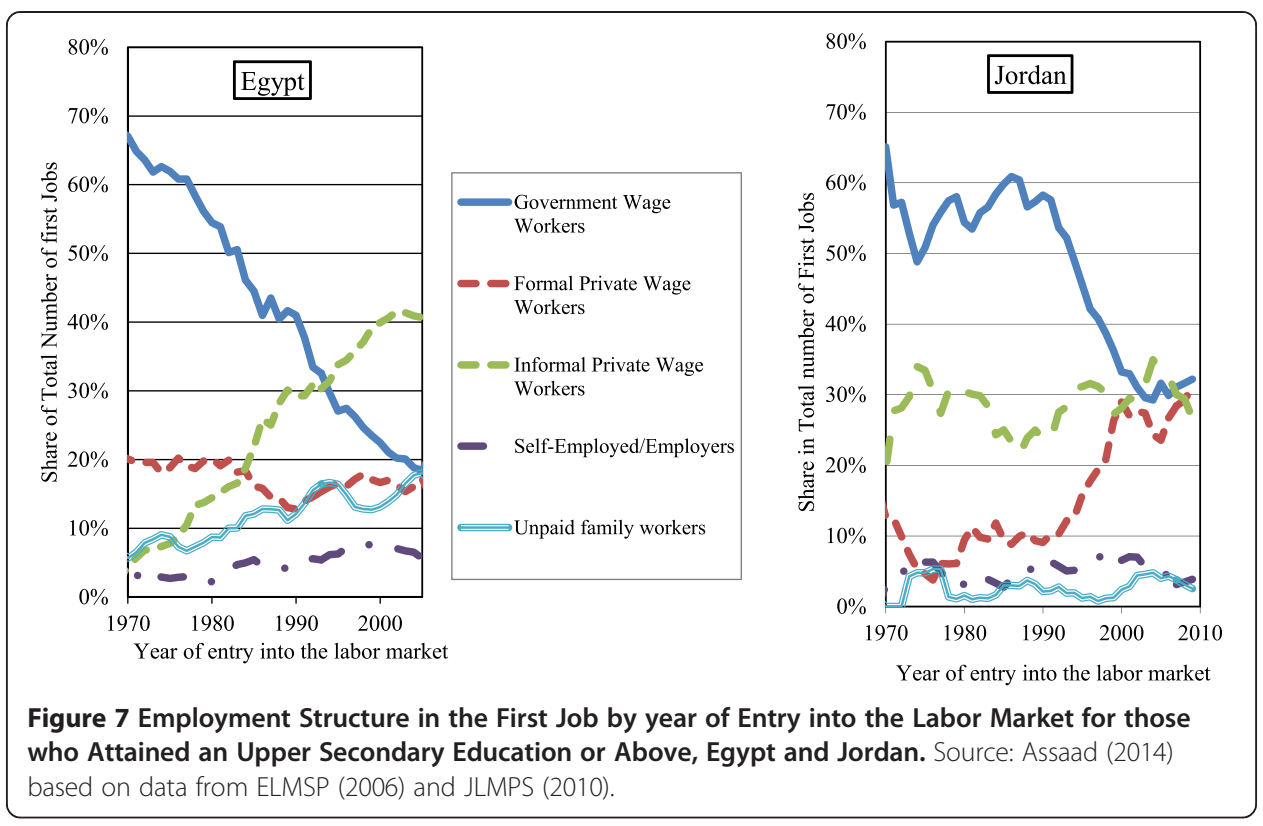


the 1990s the probability of accessing government employment even 10 years after entry was no higher than what it was at entry. The resulting informalization of the labor market for graduates in Egypt, which translates into an inability to join the ranks of the middle class, undoubtedly accounts for much of the frustration that led to the January $25^{\text {th }}$ Egyptian revolution.

The experience of graduates over time in Jordan is similar in some respects but different in others. The proportion of graduates obtaining public sector jobs in their first job also fell dramatically in Jordan over time, but it started its decline much later than in Egypt, around the late 1980s and early 1990s. It then fell rapidly, from about 60 percent to 30 percent, in just over a decade. Unlike Egypt, where the decline continued apace, the decline in Jordan slowed dramatically in the 2000s and even reversed somewhat in recent years. Also, in contrast to Egypt, where informality was the main alternative to public employment, formal private wage employment took up much of the slack in Jordan. A careful examination of the data shows that Jordan was able to avoid informalization by providing it private employers with greater flexibility in hiring and firing. The data show that a growing proportion of these formal private sector jobs was in fact jobs with temporary contracts rather than in ones with indefinite duration contracts (Assaad 2013) ${ }^{4}$.

The labor market response to reduced public sector hiring in both countries - informalization in the case of Egypt and the growth of formal but precarious temporary jobs in the private sector in Jordan - describes quite well how male job seekers have responded in the two countries. The main response among women in both instances has been high unemployment rates at first and then withdrawal from the labor force altogether and falling participation rates, an issue we discuss in more detail below. Informal employment simply poses too high a reputational risk and too much conflict with their eventual roles as wives and mothers for most female job seekers in conservative Middle Eastern societies to constitute an acceptable alternative to public sector employment (See Assaad, Hendy and Yassine 2014).

\section{Low and stagnant female labor force participation}

The very low female labor force participation in the Arab World are amply documented (cf. World Bank 2004b, World Bank 2013b). According to the World Bank's World Development Indicators, out of the twenty countries with the lowest female labor force participation rates in 2011, fifteen were Arab countries (World Bank 2013c). Some have attributed these low participation rates to the influence of conservative social norms and the value placed on female modesty in Islam (Clark et al. 1991, Miles 2002, Sidani 2005, Spierings et al. 2009, Banyanpourtehrani and Sylvester 2013). Others attribute it to the effect of oil rents on raising reservation wages, sustaining the patriarchal gender contract, or reducing demand for female labor through the Dutch disease phenomenon (Karshenas and Moghadam 2001, Ross 2008). The main question I would like to address here is not why female labor force participation rates are so low in the region, but rather why they have stagnated or increased very little, despite significant increases in educational attainment and substantial progress on closing the gender gap in education. This particular question has been referred to as the MENA "gender equality paradox." (World Bank 2013b).

A number of studies have established the strong relationship between labor force participation and education in Arab countries (Assaad and El-Hamidi, 2009, Assaad, et al. 
2013). These studies have shown convincingly that the link between participation and educational attainment is strongly mediated by the availability of government employment for educated women. The slowdown in government hiring in recent years first resulted in a drop in employment rates among women and a sharp increase in unemployment, but later translated into declines in participation among educated women in certain countries; a factor that has countered the decisive shift in favor of greater educational attainment and that has kept overall participation rates flat.

This dynamic is clearly illustrated in Figure 8, which examines various forms of female participation in economic activity by level of educational attainment in Egypt, Jordan and Tunisia over time. The first thing we note from the figure is that overall participation was not only low, but also fairly stagnant over time in all three countries. This was true despite the fact that, as we saw earlier, educational attainment rose rapidly and that participation rises significantly once women reach the post-secondary level. In both Egypt and Jordan, labor force participation actually fell among educated women in the $2000 \mathrm{~s}^{5}$. In both countries, this decline can be traced through the four
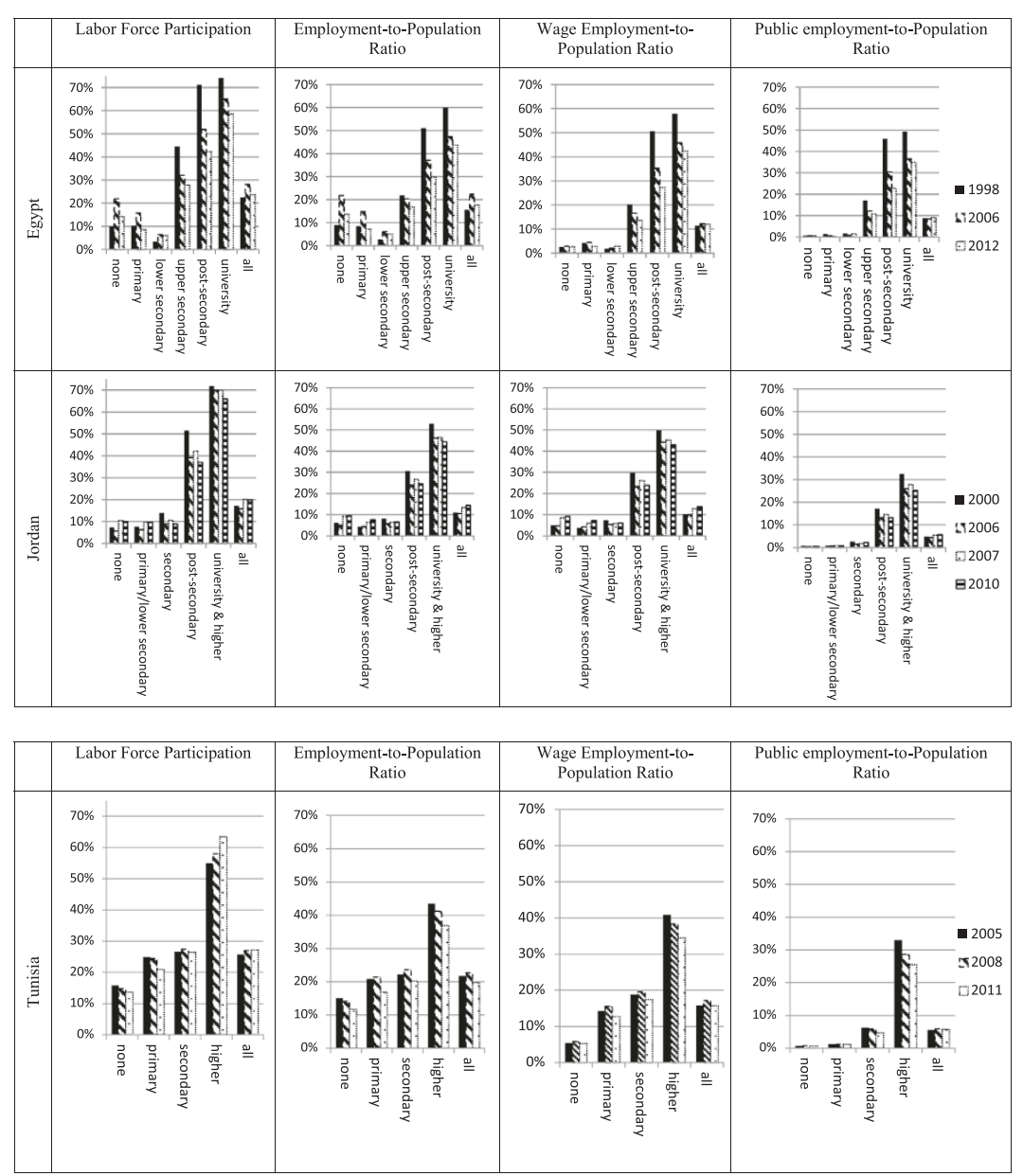

Figure 8 Female Labor Force Participation, Employment-to-Population Ratio, Wage-Employment-toPopulation Ratio and Public employment-to-Population Ratio, by Educational Attainment and Over Time for Egypt, Jordan and Tunisia. Source: Egypt Labor Market Panel Survey, 1998, 2006 and 2012. Jordan, Department of Statistics, Employment and Unemployment Survey, 2000, 2006, 2007, 2010, and Tunisia Institute of National Statistics, Labor Force Survey, 2005, 2008 and 2011. 
figures to a decline in public wage employment for educated women, which comprises the bulk of wage employment in both instances. Less educated women either participate exclusively in non-wage work (as in Egypt) or have very low participation rates (as in Jordan).

The situation in Tunisia appears different, but in fact shares many of the same features as in Egypt and Jordan. Although participation in the labor force increased over time for women with higher education in Tunisia, this increase is entirely due to rising rates of unemployment. The ratios of employment-to-population, wage employment-to-population, and public wage employment all show the same declining trend that is apparent in Egypt and Jordan. In all three countries, women with post-secondary education are strongly dependent on the government for their employment. As rates of public employment decline, their employment rates also decline, leading first to high unemployment rates among women and then to falling labor force participation rates, as in the case of Egypt and Jordan. Private wage employment was simply not a viable alternative to public sector employment for these educated women, partly because women, who would have otherwise spent their entire careers working in the public sector, either decline to take private sector jobs altogether or leave such jobs at marriage. Thus, with the curtailment of employment in the government in recent years, women are either pushed in the unemployment queue, as we will see below, or pushed out of the labor force altogether.

\section{High youth unemployment: a product of labor market dualism?}

High youth unemployment is probably the most distinctive feature of Arab labor markets. According to the ILO, the Middle East and North Africa, taken separately, are the two regions with by far the highest rates of youth unemployment in the world (ILO 2013, Annex A). The youth unemployment rates in 2012 in the Middle East and North Africa are estimated at 28.3 percent and 23.7 percent, respectively, compared to 18.1 percent in developed economies and the European Union, the region with the next highest rate. Projecting forward, the ILO estimates that the youth unemployment rate will keep rising to reach 30 percent in the Middle East by 2017 and to reach 24 percent in North Africa by 2016, whereas the peak rate in any other world region will not exceed 18 percent, the projected rate for Central and South Eastern Europe over the period 2013 to 2018. ILO estimates also show that the Middle East and North Africa are the two regions with the highest gender gap in unemployment. The female-to-male ratio in youth unemployment rates is estimated at 2.1 and 1.8 in the North Africa and the Middle East, respectively, compared to 1.5 in Latin America and the Caribbean, the region with the next highest ratio (Ibid.). The large discrepancy in unemployment rates by sex is at the country level is clearly apparent in Figure 9. The only two countries where female rates are slightly lower than males rates are Morocco and Lebanon; two countries where the public sector does not play a major role in the labor market.

Not only is the Arab world distinguished by its high youth unemployment rates, but also by the fact that they tend to rise with skill level. Figure 10 clearly shows the tendency of youth unemployment rates to rise with educational attainment for both males and females. The main exceptions to this trend, among the countries shown, is the case of Palestinians males and Syrian males and females. High unemployment among less educated Palestinian males is a well-known phenomenon related to the closure of the Israeli labor 


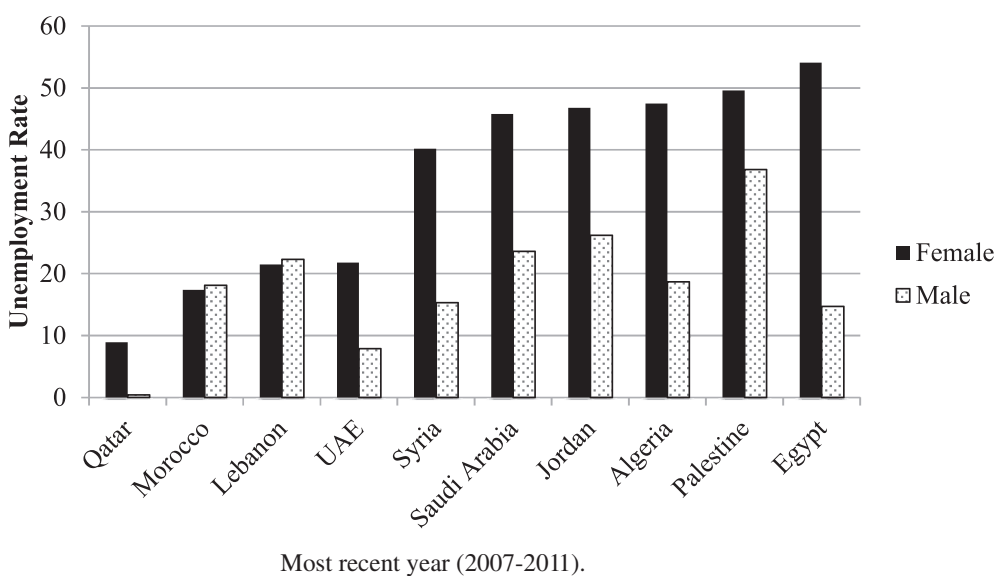

Figure 9 Youth Unemployment Rates inselected Arab Countries by Sex. Source: Author's calculation based on data from ILO (2011).

market and this group's reliance on unskilled jobs in Israel. It is not clear why unemployment is so high among less educated Syrian females. Outside these two exceptions, the rising pattern of unemployment with educational attainment is unmistakable and is consistent with the hypothesis that educated youth are queuing for public sector jobs.

To investigate this hypothesis further, I use microdata from a number of population censuses in Arab countries for which data is available in the IPUMS-International data base (Minnesota Population Center 2013). A formal test of the effects of the dualism engendered by politically-motivated public sector employment policies on youth unemployment is hard to devise because of the pervasiveness and enduring nature of these policies. However, on the assumption that job search takes place for the most part in the local jurisdiction in which the individual was born, we can devise a test based on variations in the rate of public sector employment in different geographic jurisdictions and its association with a youth's probability of being unemployed. A queuing hypothesis suggests that youth unemployment will be higher in jurisdictions with a higher share of public employment, after controlling for age, education, sex, and other jurisdictional characteristics. If, on the other hand, unemployment was caused by an

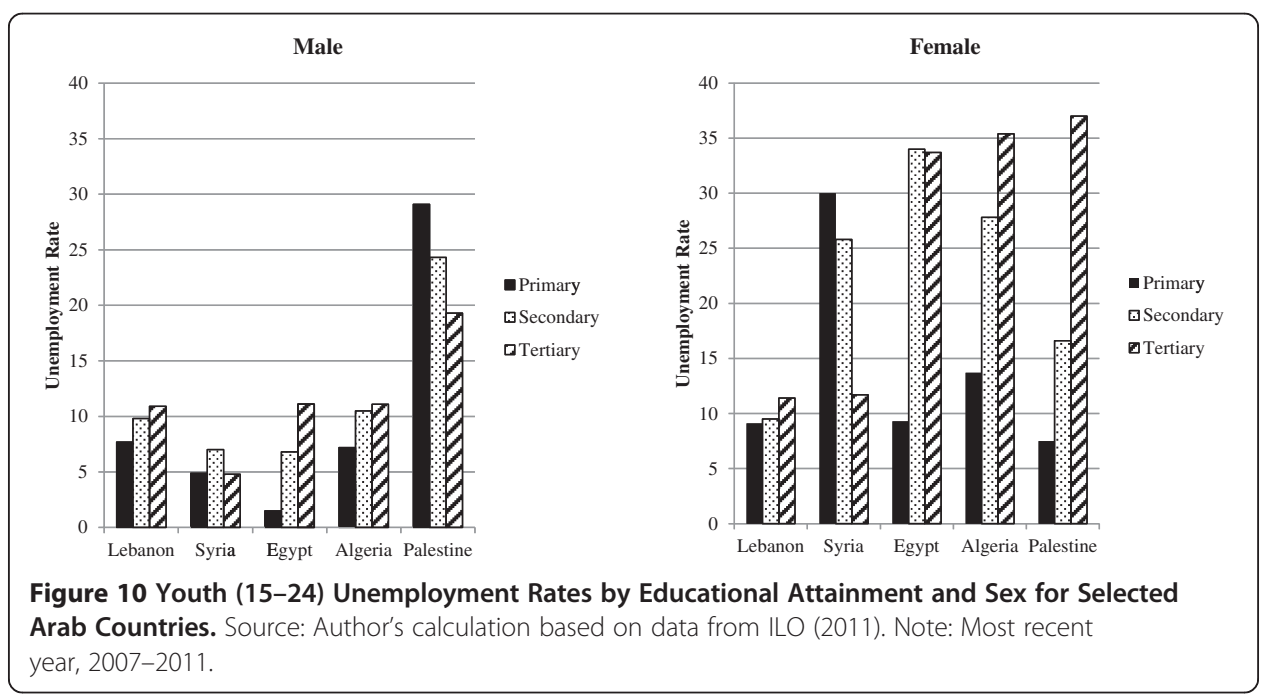


inadequacy of labor demand in the jurisdiction, we would tend to expect lower youth unemployment in jurisdiction with higher than average government employment ${ }^{6}$. If the assumption of mostly local job search is violated, the link between the structure of the local labor market and queuing behavior could be severed, making the test unreliable. The violation of the mostly local job search assumption is more likely for males than for females and for more educated workers than for less educated ones.

In all countries, I use the first level administrative geography (i.e. province or governorate of birth) to define jurisdiction ${ }^{7}$. To avoid problems associated with the endogeneity of migration, I use the jurisdiction of birth rather than that of current residence to estimate the relevant public employment rate. The sample consists of individual observations for youth 15-29 who are in the labor force from ten percent random samples of the population in seven population censuses from five countries, yielding a total sample size of 2,084,702 observations ${ }^{8}$.

To motivate the analysis, I start by looking at scatter diagrams of youth unemployment rates vs. the public employment rate at the province/governorate of birth (See Figure 11). As shown in the figure, all but two samples exhibit the expected positive relationship. The exceptions are Egypt in 1996 and Palestine in 2007. The negative relationship in Palestine in 2007 is due to the fact that most unemployment in Palestine in that year had to do with less educated male workers no longer being able to access the Israeli labor market for jobs due to the security closure of the border between Israel and the West Bank.

Having looked at the bivariate relationship between youth unemployment and the local public employment rate, I examine next the same relationship in a multivariate framework where I control for a variety of other covariates at both the individual and community levels. The individual level controls are age, sex, and educational attainment. The community level controls are urban/rural location and some governorate/province characteristics, such as prevalence of connections to basic urban services and variables indicating the

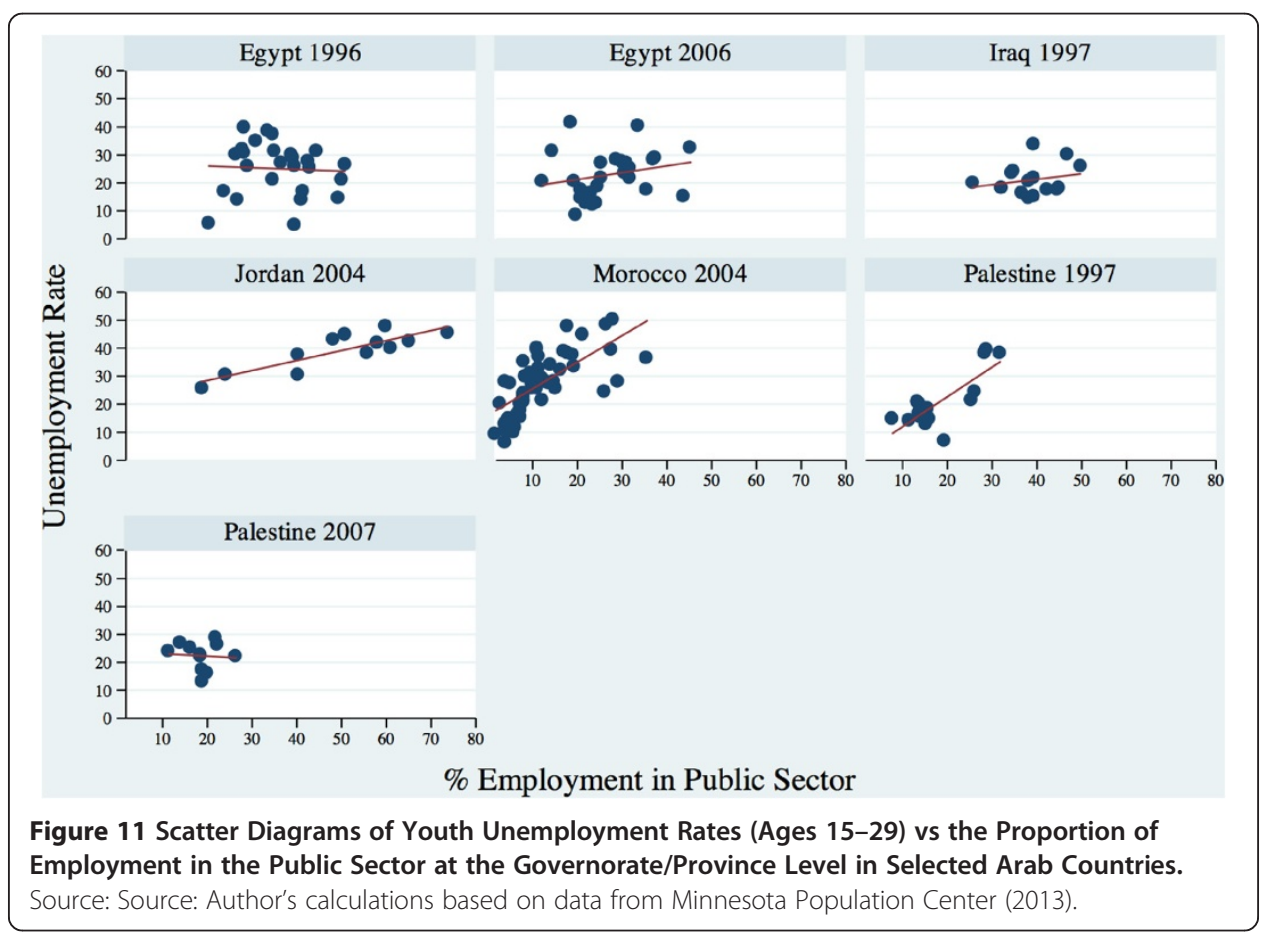


educational composition of the governorate/province population. The means of the explanatory variables are shown in Table 1.

The youth (15-29) unemployment rates in each census by various characteristics are shown in Table 2. As we have seen in Figure 10 above, unemployment rates for young women are much higher than those of young men, except for Iraq. Unemployment rates tend to be higher for more educated youth, except for Iraq and Palestine, where they are highest for the least educated. In Egypt, peak youth unemployment rates are reached at the secondary level, whereas in Jordan and Morocco they are reached at the university level. There is no systematic pattern in youth unemployment by urban/rural location.

Table 1 Means of explanatory variables, population census data, ages 15-29

\begin{tabular}{|c|c|c|c|c|c|c|c|c|}
\hline & $\begin{array}{r}\text { Egypt } \\
1996\end{array}$ & $\begin{array}{r}\text { Egypt } \\
2006\end{array}$ & $\begin{array}{r}\text { Iraq } \\
1997\end{array}$ & $\begin{array}{r}\text { Jordan } \\
2004\end{array}$ & $\begin{array}{r}\text { Morocco } \\
2004\end{array}$ & $\begin{array}{r}\text { Palestine } \\
1997\end{array}$ & $\begin{array}{r}\text { Palestine } \\
2007\end{array}$ & Total \\
\hline \multicolumn{9}{|l|}{$\begin{array}{l}\text { Individual } \\
\text { characteristics }\end{array}$} \\
\hline Age & 22.5 & 23.1 & 22.5 & 23.6 & 22.5 & 22.8 & 23.3 & 22.7 \\
\hline Age squared & 519.3 & 547.5 & 521.7 & 570.1 & 520.9 & 532.4 & 558.1 & 532.1 \\
\hline Male (\%) & 80.1 & 79.3 & 91.6 & 74.2 & 69.1 & 89.7 & 85.0 & 78.9 \\
\hline Female (\%) & 19.9 & 20.7 & 8.4 & 25.8 & 30.9 & 10.3 & 15.0 & 21.1 \\
\hline $\begin{array}{l}\text { Education: less than } \\
\text { primary (\%) }\end{array}$ & 39.6 & 27.1 & 31.3 & 7.0 & 57.8 & 10.8 & 5.2 & 36.1 \\
\hline Education: primary (\%) & 7.0 & 10.4 & 49.7 & 41.0 & 32.2 & 58.6 & 56.7 & 19.4 \\
\hline $\begin{array}{l}\text { Education: secondary } \\
\text { (\%) }\end{array}$ & 44.2 & 46.4 & 13.7 & 35.4 & 8.0 & 23.7 & 19.9 & 34.3 \\
\hline $\begin{array}{l}\text { Education: university } \\
\text { (\%) }\end{array}$ & 9.2 & 16.0 & 5.3 & 16.5 & 2.0 & 6.9 & 18.1 & 10.2 \\
\hline \multicolumn{9}{|l|}{ Urban/rural Location } \\
\hline $\begin{array}{l}\text { Urban/rural missing } \\
\text { (\%) }\end{array}$ & 0.0 & 0.0 & 0.1 & 0.0 & 100.0 & 14.8 & 5.7 & 19.2 \\
\hline Rural (\%) & 41.9 & 59.2 & 34.4 & 23.7 & 0.0 & 33.6 & 28.8 & 38.8 \\
\hline Urban (\%) & 58.1 & 40.8 & 65.4 & 76.3 & 0.0 & 51.6 & 65.6 & 42.0 \\
\hline \multicolumn{9}{|l|}{$\begin{array}{l}\text { Province/Governorate } \\
\text { characteristics }\end{array}$} \\
\hline $\begin{array}{l}\text { Public employment } \\
\text { rate }(\%)\end{array}$ & 34.9 & 26.9 & 41.0 & 35.8 & 11.1 & 18.3 & 18.1 & 27.8 \\
\hline $\begin{array}{l}\% \text { Connected to } \\
\text { electricity }\end{array}$ & 95.2 & 99.0 & 96.7 & 99.1 & 70.2 & 94.9 & 99.2 & 92.1 \\
\hline $\begin{array}{l}\% \text { Connected to piped } \\
\text { water }\end{array}$ & 71.9 & 93.7 & 78.3 & 83.8 & 53.8 & 83.4 & 80.6 & 77.6 \\
\hline $\begin{array}{l}\% \text { Connected to } \\
\text { sewerage network }\end{array}$ & 41.3 & 51.3 & 71.7 & 53.3 & 67.2 & 32.0 & 30.5 & 53.1 \\
\hline $\begin{array}{l}\% \text { w/ Secondary } \\
\text { education in working } \\
\text { age population (\%) }\end{array}$ & 23.3 & 33.9 & 13.8 & 34.3 & 8.9 & 22.5 & 25.6 & 23.8 \\
\hline $\begin{array}{l}\% \text { w/ University } \\
\text { education in working } \\
\text { age population (\%) }\end{array}$ & 6.9 & 11.0 & 5.2 & 10.6 & 2.7 & 5.7 & 9.7 & 7.5 \\
\hline N (Observations) & 679,333 & 839,128 & 233,428 & 67,750 & 218,806 & 27,239 & 19,018 & $2,084,702$ \\
\hline
\end{tabular}

Source: Author's calculations based on data from Minnesota Population Center (2013). Note: Data excludes governorates/provinces above the 99 th percentile of public employment rate. 
Table 2 Unemployment rates by various characteristics, population census data, ages 15-29

\begin{tabular}{|c|c|c|c|c|c|c|c|c|}
\hline & $\begin{array}{r}\text { Egypt } \\
1996\end{array}$ & $\begin{array}{r}\text { Egypt } \\
2006\end{array}$ & $\begin{array}{r}\text { Iraq } \\
1997\end{array}$ & $\begin{array}{r}\text { Jordan } \\
2004\end{array}$ & $\begin{array}{r}\text { Morocco } \\
2004\end{array}$ & $\begin{array}{r}\text { Palestine } \\
1997\end{array}$ & $\begin{array}{r}\text { Palestine } \\
2007\end{array}$ & Total \\
\hline Male & 23.4 & 18.7 & 22.0 & 27.9 & 22.7 & 19.5 & 22.2 & 21.5 \\
\hline Female & 50.5 & 40.2 & 4.3 & 52.6 & 36.4 & 28.1 & 31.2 & 40.9 \\
\hline $\begin{array}{l}\text { Education: Less } \\
\text { than Primary }\end{array}$ & 3.7 & 10.1 & 25.7 & 20.4 & 20.3 & 25.3 & 25.4 & 12.6 \\
\hline Education: Primary & 10.1 & 17.3 & 19.4 & 35.1 & 35.5 & 20.2 & 22.5 & 24.2 \\
\hline $\begin{array}{l}\text { Education: } \\
\text { Secondary }\end{array}$ & 53.4 & 29.3 & 14.6 & 35.2 & 37.6 & 18.9 & 22.6 & 38.3 \\
\hline $\begin{array}{l}\text { Education: } \\
\text { University }\end{array}$ & 32.5 & 31.6 & 15.6 & 36.2 & 39.5 & 19.8 & 27.2 & 31.3 \\
\hline Urban/rural missing & & & 13.3 & & 27.0 & 25.8 & 28.6 & 27.0 \\
\hline Rural & 30.2 & 18.8 & 20.9 & 42.4 & & 17.0 & 23.8 & 23.1 \\
\hline Urban & 27.8 & 29.5 & 20.3 & 31.8 & & 21.1 & 23.0 & 27.2 \\
\hline Total & 28.8 & 23.2 & 20.5 & 34.3 & 27.0 & 20.4 & 23.5 & 25.6 \\
\hline N (Observations) & 679,333 & 839,128 & 233,428 & 67,750 & 218,806 & 27,239 & 19,018 & $2,084,702$ \\
\hline
\end{tabular}

Source: Author's calculations based on data from Minnesota Population Center (2013).

Marginal effects from Probit regression of the probability of being unemployed conditional on being in the labor force for youth 15-29 are shown in Table 3. I start by running a regression for the pooled sample, with only main effects and country-year dummies. I then add interactions between sex and education, the public employment rate and education, the public employment rate and sex, and finally the public, employment rate, sex and education. In the subsequent columns I estimate regressions with the same interaction terms for each of the country-year samples independently. The reference individual in all the regressions is a 22 year-old male, with secondary education, residing in a rural area in a governorate or province with mean characteristics for the country in that year. The governorate/province characteristics, including the public employment rate, are expressed in standardized units.

Focusing initially on the pooled main effects regression (shown in the first column of Table 3), we note that the coefficient of the public employment rate is positive as expected but only significant at the 10 percent level once the individual and provincelevel controls are included. An increase in the public employment rate of one standard deviation is associated with a 2 percentage point increase in youth unemployment, on average, across all seven censuses. We also note that age has the expected inverted U-shaped effect on unemployment and that the reference young woman has an unemployment rate that is 15 percentage points higher than the reference young man. Education significantly increases unemployment up until the secondary level and then the effect levels off.

Because the results for the model with interactions are a little more difficult to interpret, I carry out simulations by varying the public employment rate from minus two standard deviations to plus two standard deviations around the mean to see its effect on the unemployment rate for different categories of youth by education and sex. The results of these simulations are shown in Figure 12. For the regression pooling all countries, we can clearly see that the public employment rate in the governorate/province of birth has a positive effect on the unemployment rate of young males and females with less than secondary education, but has no significant effect on that of secondary and 
Table 3 Marginal effects from a probit regression, all individuals Ages 15-29

\begin{tabular}{|c|c|c|c|c|c|c|c|c|c|}
\hline \multicolumn{10}{|c|}{ Dependent variable: unemployed or not for those in labor force } \\
\hline & $\begin{array}{l}\text { All Main } \\
\text { Effects }\end{array}$ & All Interacted & Egypt 1996 & Egypt 2006 & Iraq 1997 & Jordan 2004 & $\begin{array}{l}\text { Morocco } \\
2004\end{array}$ & $\begin{array}{l}\text { Palestine } \\
1997\end{array}$ & $\begin{array}{l}\text { Palestine } \\
2007\end{array}$ \\
\hline Base Probability & 0.396 & 0.387 & 0.561 & 0.244 & 0.196 & 0.320 & 0.391 & 0.190 & 0.244 \\
\hline $\begin{array}{l}\text { Public employment rate in governorate/ } \\
\text { province (SD) }\end{array}$ & $\begin{array}{l}0.020 \\
(0.012)\end{array}$ & $\begin{array}{l}-0.012 \\
(0.017)\end{array}$ & $\begin{array}{l}0.008 \\
(0.046)\end{array}$ & $\begin{array}{l}-0.015 \\
(0.018)\end{array}$ & $\begin{array}{l}0.014^{*} \\
(0.005)\end{array}$ & $\begin{array}{l}-0.015 \\
(0.017)\end{array}$ & $\begin{array}{l}0.028 \\
(0.019)\end{array}$ & $\begin{array}{l}0.030^{*} \\
(0.015)\end{array}$ & $\begin{array}{l}-0.020 \\
(0.015)\end{array}$ \\
\hline \multicolumn{10}{|l|}{ Individual characteristics } \\
\hline Age & $\begin{array}{l}0.046^{* * *} \\
(0.012)\end{array}$ & $\begin{array}{l}0.046^{* * *} \\
(0.012)\end{array}$ & $\begin{array}{l}0.113^{* * *} \\
(0.012)\end{array}$ & $\begin{array}{l}0.043^{* * *} \\
(0.004)\end{array}$ & $\begin{array}{l}-0.103^{* * *} \\
(0.005)\end{array}$ & $\begin{array}{l}-0.086^{* * *} \\
(0.010)\end{array}$ & $\begin{array}{l}0.033^{* * *} \\
(0.004)\end{array}$ & $\begin{array}{l}-0.054^{* * *} \\
(0.008)\end{array}$ & $\begin{array}{l}-0.023 \\
(0.012)\end{array}$ \\
\hline Age Sq. & $\begin{array}{l}-0.002^{* * *} \\
(0.000)\end{array}$ & $\begin{array}{l}-0.002^{* * *} \\
(0.000)\end{array}$ & $\begin{array}{l}-0.003^{* * *} \\
(0.000)\end{array}$ & $\begin{array}{l}-0.002^{* * *} \\
(0.000)\end{array}$ & $\begin{array}{l}0.002^{* * *} \\
(0.000)\end{array}$ & $\begin{array}{l}0.001^{* * *} \\
(0.000)\end{array}$ & $\begin{array}{l}-0.001^{* * *} \\
(0.000)\end{array}$ & $\begin{array}{l}0.001^{* * *} \\
(0.000)\end{array}$ & $\begin{array}{l}-0.000 \\
(0.000)\end{array}$ \\
\hline Female & $\begin{array}{l}0.152^{* * *} \\
(0.012)\end{array}$ & $\begin{array}{l}0.182^{* * *} \\
(0.015)\end{array}$ & $\begin{array}{l}0.131^{* * *} \\
(0.015)\end{array}$ & $\begin{array}{l}0.198^{* * *} \\
(0.018)\end{array}$ & $\begin{array}{l}-0.270^{* * *} \\
(0.016)\end{array}$ & $\begin{array}{l}0.372^{* * *} \\
(0.008)\end{array}$ & $\begin{array}{l}0.021 \\
(0.020)\end{array}$ & $\begin{array}{l}0.065^{* *} \\
(0.021)\end{array}$ & $\begin{array}{l}0.133^{* * *} \\
(0.026)\end{array}$ \\
\hline \multicolumn{10}{|l|}{ Education Level, Secondary Omitted } \\
\hline Ed. LT primary & $\begin{array}{l}-0.415^{\text {*** }} \\
(0.043)\end{array}$ & $\begin{array}{l}-0.398^{* * *} \\
(0.043)\end{array}$ & $\begin{array}{l}-0.762^{* * *} \\
(0.031)\end{array}$ & $\begin{array}{l}-0.229^{* * *} \\
(0.017)\end{array}$ & $\begin{array}{l}-0.014^{*} \\
(0.007)\end{array}$ & $\begin{array}{l}-0.057^{*} \\
(0.023)\end{array}$ & $\begin{array}{l}-0.238^{* * *} \\
(0.018)\end{array}$ & $\begin{array}{l}0.008 \\
(0.014)\end{array}$ & $\begin{array}{l}0.046^{*} \\
(0.020)\end{array}$ \\
\hline Ed. primary & $\begin{array}{l}-0.238^{* * *} \\
(0.030)\end{array}$ & $\begin{array}{l}-0.241^{* * *} \\
(0.031)\end{array}$ & $\begin{array}{l}-0.581^{* * *} \\
(0.033)\end{array}$ & $\begin{array}{l}-0.154^{* * *} \\
(0.014)\end{array}$ & $\begin{array}{l}-0.049^{* * *} \\
(0.007)\end{array}$ & $\begin{array}{l}0.023^{* *} \\
(0.008)\end{array}$ & $\begin{array}{l}-0.083^{* * *} \\
(0.013)\end{array}$ & $\begin{array}{l}-0.015 \\
(0.009)\end{array}$ & $\begin{array}{l}-0.006 \\
(0.014)\end{array}$ \\
\hline Ed. University & $\begin{array}{l}-0.023 \\
(0.015)\end{array}$ & $\begin{array}{l}0.045^{* *} \\
(0.015)\end{array}$ & $\begin{array}{l}-0.044^{* * *} \\
(0.010)\end{array}$ & $\begin{array}{l}0.110^{* * *} \\
(0.012)\end{array}$ & $\begin{array}{l}0.025^{*} \\
(0.011)\end{array}$ & $\begin{array}{l}0.126^{* * *} \\
(0.010)\end{array}$ & $\begin{array}{l}0.060 \\
(0.032)\end{array}$ & $\begin{array}{l}0.058^{* *} \\
(0.018)\end{array}$ & $\begin{array}{l}0.098^{* * *} \\
(0.020)\end{array}$ \\
\hline \multicolumn{10}{|l|}{ Residence, rural omitted } \\
\hline Urban/Rural missing & $\begin{array}{l}0.104^{* * *} \\
(0.028)\end{array}$ & $\begin{array}{l}0.104^{* * *} \\
(0.027)\end{array}$ & & & $\begin{array}{l}-0.104^{*} \\
(0.051)\end{array}$ & & & $\begin{array}{l}-0.002 \\
(0.017)\end{array}$ & $\begin{array}{l}0.062^{* *} \\
(0.024)\end{array}$ \\
\hline Urban & $\begin{array}{l}0.055^{* * *} \\
(0.012)\end{array}$ & $\begin{array}{l}0.053^{* * *} \\
(0.012)\end{array}$ & $\begin{array}{l}0.002 \\
(0.013)\end{array}$ & $\begin{array}{l}0.101^{* * *} \\
(0.011)\end{array}$ & $\begin{array}{l}0.019 \\
(0.017)\end{array}$ & $\begin{array}{l}-0.046^{* *} \\
(0.017)\end{array}$ & & $\begin{array}{l}0.004 \\
(0.012)\end{array}$ & $\begin{array}{l}-0.017 \\
(0.019)\end{array}$ \\
\hline \multicolumn{10}{|l|}{ Governorate/Province Controls (Standardized) } \\
\hline Percentage connected to electricity (SD) & $\begin{array}{l}0.009 \\
(0.009)\end{array}$ & $\begin{array}{l}0.006 \\
(0.009)\end{array}$ & $\begin{array}{l}0.034 \\
(0.027)\end{array}$ & $\begin{array}{l}0.020 \\
(0.013)\end{array}$ & $\begin{array}{l}-0.040^{* * *} \\
(0.012)\end{array}$ & $\begin{array}{l}0.004 \\
(0.004)\end{array}$ & $\begin{array}{l}0.053^{*} \\
(0.025)\end{array}$ & $\begin{array}{l}0.015 \\
(0.010)\end{array}$ & $\begin{array}{l}0.035^{* * *} \\
(0.010)\end{array}$ \\
\hline
\end{tabular}


Table 3 Marginal effects from a probit regression, all individuals Ages 15-29 (Continued)

\begin{tabular}{|c|c|c|c|c|c|c|c|c|c|}
\hline Percentage connected to piped water (SD) & $\begin{array}{l}0.017 \\
(0.012)\end{array}$ & $\begin{array}{l}0.014 \\
(0.012)\end{array}$ & $\begin{array}{l}-0.015 \\
(0.035)\end{array}$ & $\begin{array}{l}-0.004 \\
(0.018)\end{array}$ & $\begin{array}{l}-0.013 \\
(0.021)\end{array}$ & $\begin{array}{l}-0.004 \\
(0.006)\end{array}$ & $\begin{array}{l}-0.005 \\
(0.020)\end{array}$ & $\begin{array}{l}-0.018^{*} \\
(0.009)\end{array}$ & $\begin{array}{l}-0.016 \\
(0.010)\end{array}$ \\
\hline Percentage connected to sewerage network (SD) & $\begin{array}{l}0.016 \\
(0.013)\end{array}$ & $\begin{array}{l}0.020 \\
(0.011)\end{array}$ & $\begin{array}{l}0.051 \\
(0.040)\end{array}$ & $\begin{array}{l}0.019 \\
(0.022)\end{array}$ & $\begin{array}{l}0.074 \\
(0.039)\end{array}$ & $\begin{array}{l}-0.062^{* * *} \\
(0.013)\end{array}$ & $\begin{array}{l}0.023 \\
(0.012)\end{array}$ & $\begin{array}{l}-0.018^{*} \\
(0.009)\end{array}$ & $\begin{array}{l}-0.013 \\
(0.012)\end{array}$ \\
\hline $\begin{array}{l}\text { Percentage w/ secondary educ. in working age } \\
\text { pop. (SD) }\end{array}$ & $\begin{array}{l}-0.019 \\
(0.017)\end{array}$ & $\begin{array}{l}-0.016 \\
(0.016)\end{array}$ & $\begin{array}{l}-0.107^{* *} \\
(0.040)\end{array}$ & $\begin{array}{l}0.028 \\
(0.020)\end{array}$ & $\begin{array}{l}-0.045^{*} \\
(0.023)\end{array}$ & $\begin{array}{l}0.044^{* * *} \\
(0.008)\end{array}$ & $\begin{array}{l}0.025 \\
(0.020)\end{array}$ & $\begin{array}{l}0.063^{* * *} \\
(0.011)\end{array}$ & $\begin{array}{l}0.028 \\
(0.015)\end{array}$ \\
\hline $\begin{array}{l}\text { Percentage w/ university educ. in working age } \\
\text { pop. (SD) }\end{array}$ & $\begin{array}{l}-0.020 \\
(0.011)\end{array}$ & $\begin{array}{l}-0.023^{*} \\
(0.011)\end{array}$ & $\begin{array}{l}-0.037 \\
(0.036)\end{array}$ & $\begin{array}{l}-0.024 \\
(0.015)\end{array}$ & $\begin{array}{l}-0.014 \\
(0.018)\end{array}$ & $\begin{array}{l}-0.044^{* * *} \\
(0.004)\end{array}$ & $\begin{array}{l}-0.056^{* * *} \\
(0.017)\end{array}$ & $\begin{array}{l}-0.033^{* * *} \\
(0.006)\end{array}$ & $\begin{array}{l}-0.040^{* * *} \\
(0.010)\end{array}$ \\
\hline \multicolumn{10}{|l|}{ Gender \& education interactions } \\
\hline Female * Ed LT. primary & & $\begin{array}{l}-0.027 \\
(0.021)\end{array}$ & $\begin{array}{l}0.020 \\
(0.035)\end{array}$ & $\begin{array}{l}-0.037 \\
(0.023)\end{array}$ & $\begin{array}{l}-0.037 \\
(0.026)\end{array}$ & $\begin{array}{l}-0.461^{* * *} \\
(0.052)\end{array}$ & $\begin{array}{l}0.140^{* * *} \\
(0.016)\end{array}$ & $\begin{array}{l}0.088 \\
(0.050)\end{array}$ & $\begin{array}{l}-0.012 \\
(0.080)\end{array}$ \\
\hline Female * ed. primary & & $\begin{array}{l}0.030^{*} \\
(0.015)\end{array}$ & $\begin{array}{l}0.155^{* * *} \\
(0.033)\end{array}$ & $\begin{array}{l}0.016 \\
(0.011)\end{array}$ & $\begin{array}{l}0.004 \\
(0.025)\end{array}$ & $\begin{array}{l}-0.099^{* * *} \\
(0.025)\end{array}$ & $\begin{array}{l}0.175^{* * *} \\
(0.008)\end{array}$ & $\begin{array}{l}0.110^{* * *} \\
(0.031)\end{array}$ & $\begin{array}{l}-0.015 \\
(0.030)\end{array}$ \\
\hline Female * ed. university & & $\begin{array}{l}-0.176^{* * *} \\
(0.014)\end{array}$ & $\begin{array}{l}-0.210^{* * *} \\
(0.014)\end{array}$ & $\begin{array}{l}-0.185^{* * *} \\
(0.018)\end{array}$ & $\begin{array}{l}0.098^{* * *} \\
(0.017)\end{array}$ & $\begin{array}{l}-0.217^{* * *} \\
(0.008)\end{array}$ & $\begin{array}{l}-0.025 \\
(0.022)\end{array}$ & $\begin{array}{l}-0.088^{* * *} \\
(0.024)\end{array}$ & $\begin{array}{l}-0.078^{* * *} \\
(0.023)\end{array}$ \\
\hline \multicolumn{10}{|l|}{ Public sector \& education interactions } \\
\hline Public sector rate * ed. LT primary & & $\begin{array}{l}0.081^{*} \\
(0.032)\end{array}$ & $\begin{array}{l}0.174^{* * *} \\
(0.020)\end{array}$ & $\begin{array}{l}0.016 \\
(0.010)\end{array}$ & $\begin{array}{l}0.010^{*} \\
(0.005)\end{array}$ & $\begin{array}{l}0.054^{* *} \\
(0.018)\end{array}$ & $\begin{array}{l}0.034^{* *} \\
(0.012)\end{array}$ & $\begin{array}{l}0.030^{*} \\
(0.013)\end{array}$ & $\begin{array}{l}0.007 \\
(0.023)\end{array}$ \\
\hline Public sector rate * ed. primary & & $\begin{array}{l}0.058^{* *} \\
(0.020)\end{array}$ & $\begin{array}{l}0.127^{* * *} \\
(0.027)\end{array}$ & $\begin{array}{l}0.014 \\
(0.010)\end{array}$ & $\begin{array}{l}0.008 \\
(0.006)\end{array}$ & $\begin{array}{l}0.040^{* * *} \\
(0.006)\end{array}$ & $\begin{array}{l}0.038^{* *} \\
(0.013)\end{array}$ & $\begin{array}{l}0.018^{* *} \\
(0.007)\end{array}$ & $\begin{array}{l}-0.000 \\
(0.012)\end{array}$ \\
\hline Public sector rate * ed. university & & $\begin{array}{l}0.013 \\
(0.015)\end{array}$ & $\begin{array}{l}0.030^{* *} \\
(0.010)\end{array}$ & $\begin{array}{l}-0.006 \\
(0.009)\end{array}$ & $\begin{array}{l}0.021^{*} \\
(0.008)\end{array}$ & $\begin{array}{l}-0.004 \\
(0.007)\end{array}$ & $\begin{array}{l}-0.034 \\
(0.019)\end{array}$ & $\begin{array}{l}0.019 \\
(0.017)\end{array}$ & $\begin{array}{l}0.009 \\
(0.018)\end{array}$ \\
\hline \multicolumn{10}{|l|}{ Public sector \& gender interaction } \\
\hline Public sector rate * female & & $\begin{array}{l}-0.027^{*} \\
(0.013)\end{array}$ & $\begin{array}{l}-0.033^{*} \\
(0.013)\end{array}$ & $\begin{array}{l}-0.021 \\
(0.011)\end{array}$ & $\begin{array}{l}0.026 \\
(0.014)\end{array}$ & $\begin{array}{l}0.093^{* * *} \\
(0.011)\end{array}$ & $\begin{array}{l}0.019 \\
(0.011)\end{array}$ & $\begin{array}{l}0.004 \\
(0.018)\end{array}$ & $\begin{array}{l}0.003 \\
(0.020)\end{array}$ \\
\hline \multicolumn{10}{|l|}{ Public sector, gender, \& education interactions } \\
\hline Public sector rate * female ed. LT primary & & $\begin{array}{l}0.036 \\
(0.026)\end{array}$ & $\begin{array}{l}-0.030 \\
(0.033)\end{array}$ & $\begin{array}{l}0.032 \\
(0.021)\end{array}$ & $\begin{array}{l}-0.041 \\
(0.028)\end{array}$ & $\begin{array}{l}0.080^{*} \\
(0.039)\end{array}$ & $\begin{array}{l}-0.017 \\
(0.019)\end{array}$ & $\begin{array}{l}-0.028 \\
(0.045)\end{array}$ & $\begin{array}{l}-0.365^{* *} \\
(0.126)\end{array}$ \\
\hline
\end{tabular}


Table 3 Marginal effects from a probit regression, all individuals Ages 15-29 (Continued)

\begin{tabular}{|c|c|c|c|c|c|c|c|c|c|}
\hline Public sector rate ${ }^{*}$ female* ed. primary & & $\begin{array}{l}0.037^{*} \\
(0.016)\end{array}$ & $\begin{array}{l}-0.116^{* * *} \\
(0.029)\end{array}$ & $\begin{array}{l}0.019 \\
(0.011)\end{array}$ & $\begin{array}{l}-0.005 \\
(0.029)\end{array}$ & $\begin{array}{l}-0.011 \\
(0.035)\end{array}$ & $\begin{array}{l}-0.046^{* * *} \\
(0.010)\end{array}$ & $\begin{array}{l}-0.033 \\
(0.039)\end{array}$ & $\begin{array}{l}-0.033 \\
(0.028)\end{array}$ \\
\hline Public sector rate ${ }^{*}$ female* ed. university & & $\begin{array}{l}0.052^{* * *} \\
(0.012)\end{array}$ & $\begin{array}{l}0.060^{* * *} \\
(0.013)\end{array}$ & $\begin{array}{l}0.051^{* * *} \\
(0.012)\end{array}$ & $\begin{array}{l}-0.029^{*} \\
(0.014)\end{array}$ & $\begin{array}{l}-0.054^{* * *} \\
(0.007)\end{array}$ & $\begin{array}{l}0.008 \\
(0.010)\end{array}$ & $\begin{array}{l}-0.020 \\
(0.023)\end{array}$ & $\begin{array}{l}0.047^{*} \\
(0.024)\end{array}$ \\
\hline \multicolumn{10}{|l|}{$\begin{array}{l}\text { Country-year fixed effects (Egypt } 1996 \\
\text { omitted) }\end{array}$} \\
\hline Egypt 2006 & $\begin{array}{l}-0.081^{* * *} \\
(0.021)\end{array}$ & $\begin{array}{l}-0.081^{* * *} \\
(0.020)\end{array}$ & & & & & & & \\
\hline Iraq 1997 & $\begin{array}{l}0.012 \\
(0.034)\end{array}$ & $\begin{array}{l}0.016 \\
(0.037)\end{array}$ & & & & & & & \\
\hline Jordan 2004 & $\begin{array}{l}0.050 \\
(0.038)\end{array}$ & $\begin{array}{l}0.052 \\
(0.040)\end{array}$ & & & & & & & \\
\hline Morocco 2004 & $\begin{array}{l}0.054 \\
(0.034)\end{array}$ & $\begin{array}{l}0.053 \\
(0.033)\end{array}$ & & & & & & & \\
\hline Palestine 1997 & $\begin{array}{l}-0.063 \\
(0.033)\end{array}$ & $\begin{array}{l}-0.056 \\
(0.032)\end{array}$ & & & & & & & \\
\hline Palestine 2007 & $\begin{array}{l}-0.036 \\
(0.025)\end{array}$ & $\begin{array}{l}-0.028 \\
(0.023)\end{array}$ & & & & & & & \\
\hline N (Observations) Pseudo R-squared & $\begin{array}{l}2,084,702 \\
0.129\end{array}$ & $\begin{array}{l}2,084,702 \\
0.135\end{array}$ & $679,3330.320$ & $839,1280.149$ & $233,4280.077$ & $67,7500.151$ & $218,8060.072$ & $27,2390.082$ & $19,0180.062$ \\
\hline
\end{tabular}

Statistical significance is marked by ${ }^{*}$ at $5 \%, * *$ at $1 \%$ and $* * *$ at $0.1 \%$.

Standard Errors clustered at Country-year-governorate/province level.

Governorates/provinces with a public employment rate above the 99 th percentile are excluded from the sample.

Reference case: Male, Secondary, age 22 at mean for province/governorate characteristics. 

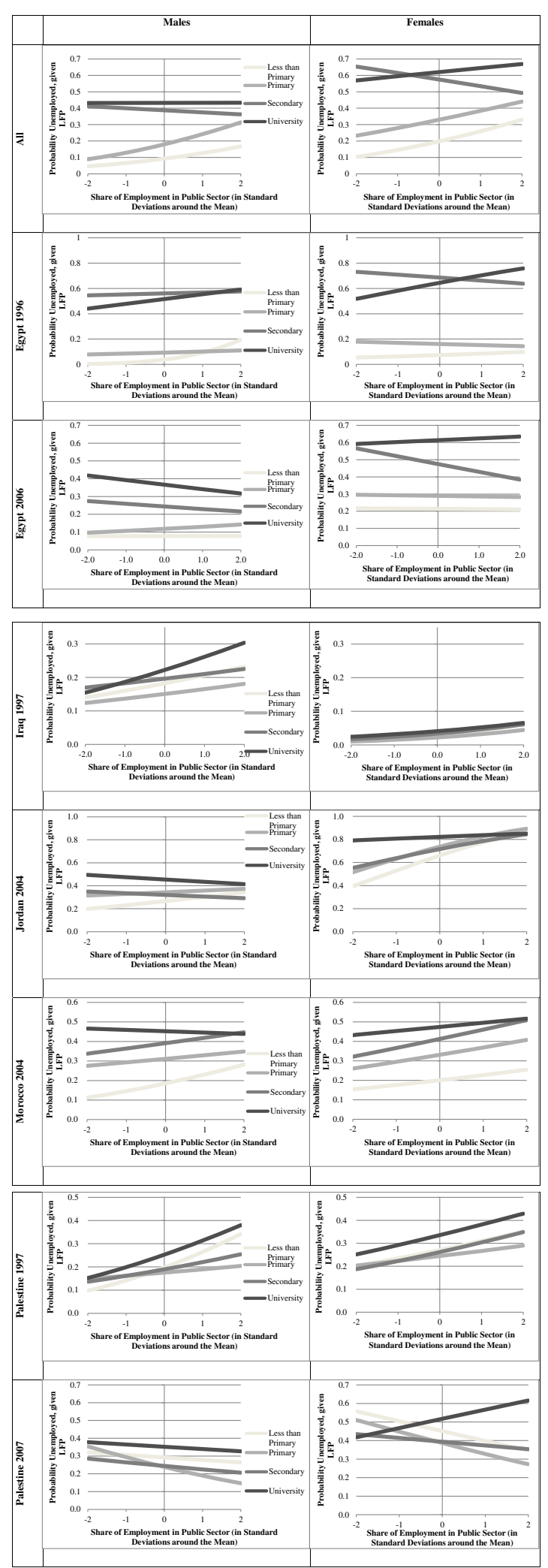

Figure 12 Youth Unemployment Rate by Share of Employment in the Public Sector in the Province/ Governorate of Birth, Simulations from Probit Regression. Source: Author's calculations based on data from Minnesota Population Center (2013). 
university educated youth. The absence of an effect for the more educated youth is surprising at first and seems to contradict our hypothesis that public employment policies are likely to segment the labor market for the educated more than for the uneducated. However, it could just be that the job search of educated youth has a broader geographic scope than that of uneducated youth and that they look for work well beyond their governorate or province of birth. If that were the case, it would explain why educated youth have higher unemployment rates even in governorates with low rates of public employment.

Moving now to the individual country results, we note that in Egypt in 1996, queuing for public sector job tends to be most pronounced among university graduates and especially female graduates who have the strongest positive relationship between their unemployment rate and the prevalence of public employment in the governorate of birth. By 2006, this positive relationship appears to have disappeared for male graduates and weakened significantly for female graduates.

Iraq in 1997 provides strong evidence in favor of the queuing hypothesis. It exhibits a strong positive relationship between youth unemployment and the prevalence of public employment in the province of birth for all educational and sex groups. For a one standard deviation increase in the prevalence of public employment, the unemployment rate of a reference Iraqi male youth with a university degree increases by 4 percentage points, a relative increase of 18 percent. At 27 percent, the relative increase in unemployment for female Iraqi graduates is also quite large although it is from a relatively low base.

In Jordan in 2004, there is direct evidence of queuing for males with less than primary education and for females with less than university education. Females with university education there have very high unemployment predicted unemployment rates in excess of 80 percent and could very well be queuing for public jobs in the national labor market. In Morocco in 2004, there is a positive relationship between the youth unemployment rate and the prevalence of public jobs in the province, for all groups except for male university graduates. Again, given their high unemployment rates, the absence of a positive relationship for this group does not mean that they do not queue for public jobs, but that their job search is probably not limited to their province of birth.

The Palestinian case is interesting because of the strong reversal that occurs between 1997, when the Israeli labor market was still fairly open for less educated makes, and 2007, when the security-related closure made strongly affected the employment prospects of this group. In 1997, there is a strong positive relationship between youth unemployment and the prevalence of public employment for all educational groups and for both sexes. This was a time that the Palestinian authority was building up its ranks and when it was probably still worthwhile for young people to queue for government jobs. By 2007 when the labor market situation became much less favorable, the only group that appears to be queuing in any significant fashion is female university graduates who have few employment prospects outside the public sector.

To summarize the results of the multivariate analysis, we can say the following. Youth unemployment has a positive relationship with the local rate of government employment for youth with less than secondary education of both sexes in the pooled sample and in four of the seven country-year samples. The exceptions are Egypt 1996 
and 2006, where there is either mixed pattern or evidence of a weak positive relationship, and Palestine 2007, where unemployment was more likely to be driven by the effects of the closure of the border with Israel than by queuing for government employment. Although government employment is rare for people with less than secondary education, this group is the most likely to restrict its job search to the local area and therefore to be affected by local public employment rates. For youth educated at the secondary level, there is a positive relationship with local government employment rates for both sexes in Iraq, Morocco, and Palestine 1997, and for women in Jordan. For those educated at the university level, there is a positive relationship for both sexes in Egypt 1996, Palestine 1997, and for women in the pooled sample, Egypt 2006, Morocco and Palestine 2007. It is not surprising that the evidence in favor of queuing for government jobs is stronger for educated women since they are likely to be more geographically constrained in their job search and their behavior would therefore more likely be governed by local conditions than their male counterparts who would probably have a more national job search strategy. On the whole, there is ample evidence of youth unemployment being associated with queuing for government jobs, with the evidence being admittedly weaker for groups for whom our test is least likely to be valid.

\section{Conclusion}

I argue in this paper that the longstanding practice of providing public sector employment at higher than market-clearing compensation as a tool of political appeasement has not only led to the misallocation of human capital in Arab economies, but also to the wrong kinds of human capital investments, and inefficient queuing by educated workers for government jobs. The consequences of these disastrous policies persist well after the policies themselves have been suspended and continue to shape labor markets in the long term. They include the large overhang of excess employment in the public sector, the existence of large stocks of inappropriate human capital, one of the longest lived assets in the economy, continued institutional distortions in education systems, which continue to be oriented toward credentialism rather than skill formation, and distorted expectations among young job seekers that lead to queuing for public sector jobs and high youth unemployment. Female job seekers are more affected by this kind of labor market dualism because of the more limited opportunities they face in the private sector, the bigger wedge they face between their market clearing wage and their potential compensation in the public sector, and their reluctance to take up informal employment that could threaten their sexual and reputational safety. As such they face higher unemployment rates and, more recently, increasing discouragement from participating in the workforce altogether.

I also argue that the erosion of the authoritarian bargain social contract was done in such a way as to protect the gains and entitlements of regime insiders and incumbents. This means that the entire cost of adjustment was shifted onto the younger generations who had come to expect the same benefits that their older counterparts received upon acquiring education. Instead they found themselves shut out of government jobs and relegated to low quality jobs in the informal economy. The failure of the Arab economies to develop dynamic, competitive private sectors that are integrated into world markets can itself be attributed to the rentier nature of these economies. The 
frustrations of a generation of young people, who have achieved increasing levels of schooling but obtained few valuable labor market skills and even fewer economic opportunities, have clearly contributed to the Arab Spring uprisings in the countries whose regimes could no longer afford the authoritarian bargain. For now, the oil rich monarchies are able to continue to buy political stability with generous welfare payments and lucrative jobs in the public sector for their citizens, but the limits of this approach will undoubtedly become clear by the time of the next downturn in oil prices. At that point the social and political costs of highly segmented labor markets will become wholly apparent.

I acknowledge that the evidence I provided to support my arguments about the impact of the region's political economy on labor market and human capital outcomes, although compelling, is mostly circumstantial. A formal statistical test of the effects of such an enduring and pervasive practice as the use of public sector employment as a tool for political appeasement is hard to come by. My attempt at a formal test of the hypothesis that queuing for government jobs explains high youth unemployment rates does provide support for the hypothesis but also suffers from some obvious limitations. Because the test depends on local variation in the availability of government jobs to drive differences in local youth unemployment rates, it relies on the assumption that youth job search behavior is mostly limited to local labor markets. While that may be true for the most part for some youth, such as young women and possibly lesser educated young men, it is not likely to be true for more educated men, who probably search for jobs in a national, if not international, labor market. Thus the absence of a positive association between high local rates of public employment and unemployment for these groups does not mean that queuing for government jobs is not taking place at a broader scale.

\section{Endnotes}

${ }^{1}$ The analysis in this section draws on Assaad (1997).

${ }^{2}$ Using data from 1988, Assaad (1999) estimates that non-wage aspects of employment in the Egyptian public sector are worth at least as much as the wage itself.

${ }^{3}$ The data is obtained from the Egypt Labor Market Survey of 2006 (ELMPS 2006) and the Jordan Labor Market Survey of 2010 (JLMPS 2010). The surveys inquire about the timing of first labor market entry and the type of job obtained at that time for individuals in various cohorts.

${ }^{4}$ Egypt implemented labor law reforms that allowed employers issue indefinite duration contracts that could be renewed an indefinite number of times only in 2004. These reforms would therefore not be reflected in this data, which ends in 2005.

${ }^{5}$ Because of a change in sampling frame, there is a break in the Jordanian data between the last quarter of 2006 and the first quarter of 2007, which resulted in an artificial increase in female participation rates. Because of that, it is best to compare 2000 to 2006 and 2007 to 2010. See Assaad et al. (2013) for further discussion of this issue.

${ }^{6}$ It is possible that causality is in the reverse direction and that government place more jobs in high unemployment areas. This would be the case, for instance, if public works programs were creating a lot of temporary public jobs in depressed areas. There are few such programs in the countries we are studying and most government jobs tend 
to be permanent jobs in the bureaucracy and security services, which are unlikely to be linked to how depressed a region is.

${ }^{7}$ There were 27 such jurisdictions in 1996 and 29 in 2006 in Egypt, 15 in 1997 in Iraq, 12 in 2004 in Jordan, 60 in 2004 in Morocco, and 16 in 1997 and 11 in 2007 in Palestine. The difference between the number of jurisdictions in Palestine in 1997 and 2007 was due to the fact that Gaza was not covered in the 2007 Palestinian Census due to political and security considerations.

${ }^{8}$ I trim the sample to exclude governorates/provinces with a public employment rate that is larger than the $99^{\text {th }}$ percentile to avoid the undue influence of small province with very high public employment rates.

Competing interests

The IZA Journal of Labor \& Development is committed to the IZA Guiding Principles of Research Integrity. The author declares that he has observed these principles.

\section{Author's information}

R.A. is professor at the Humphrey School of Public Affairs at the University of Minnesota. He is a Research Fellow of IZA and the Economic Research Forum (Cairo, Egypt), where he is the thematic leader for Labor and Human Resource Development. He is also Non-Resident Senior Fellow at the Global Economy and Development Program of the Brookings Institution (Washington DC). He was the technical director for the Egypt Labor Market Panel Survey rounds of 1998, 2006 and 2012 and the Jordan Labor Market Panel Survey round of 2010.

\section{Acknowledgments}

The author wishes to acknowledge useful comments from participants at an IZA Workshop on Labor Markets and Labor Policy in MENA countries and excellent research assistance from Caroline Krafft.

Responsible editor: Jackline Wahba

Received: 14 August 2013 Accepted: 15 March 2014

Published: 25 Apr 2014

\section{References}

Ali O, Elbadawi I (2012) The Political Economy of Public Sector Employment in Resource Dependent Countries. ERF Working Paper \# 673. Economic Research Forum, Cairo, Egypt

Amin M, Assaad R, Al-Baharna N, Dervis K, Desai R, Dhillon N, Galal A, Ghanem H, Graham C, Kaufmann D, Kharas H, Page J, Salehi-Isfahani D, Sierra K, Yousef T (2012) After the Spring: Economic Transitions in the Arab World. Oxford University Press, Oxford

Assaad R (2013) The Structure and Evolution of Employment in Jordan. In: Assaad R (ed) The Jordanian Labor Market In the New Millennium. Oxford University Press (forthcoming), Oxford

Assaad R (2014) The Structure and Evolution of Employment in Jordan. In: Assaad R (Ed.) The Jordanian Labour Market in the New Millennium. Oxford: Oxford University Press, pp 1-38

Assaad R (1999) Matching severance payments with worker losses in the Egyptian public sector. World Bank Econ Rev 13(1):117-153

Assaad R (1997) The Effects of public sector hiring and compensation policies on the Egyptian labor market. World Bank Econ Rev 11(1):85-118

Assaad R, El-Hamidi F (2009) Women in the Egyptian Labor Market: An Analysis of Developments, 1988-2006. In: Assaad R (ed) The Egyptian Labor Market Revisited. American University in Cairo Press, Cairo, pp 219-257

Assaad R, Hendy R, Yassine C (2013) Gender and the Jordanian Labor Market. In: Assaad R (ed) The Jordanian Labor Market in the New Millennium. Oxford University Press (forthcoming), Oxford

Baldwin-Edwards M (2011) Labour immigration and labour markets in the GCC countries: National patterns and trends. LSE Kuwait Programme on Development, London

Barro R, Lee J (2010) A new data set of educational attainment in the world 1950-2010. NBER Working Paper 15902. National Bureau of Economic Research, Cambridge, MA

Bayanpourtehrani G, Sylwester K (2013) Female labour force participation and Religion: a cross-country analysis. Bull Econ Res 65(2):107-133

Campante FR, Chor D (2012) "Why was the Arab World poised for revolution? Schooling economic opportunities, and the Arab Spring. J Econ Perspect 26(2):167-188

Center MP (2013) Integrated Public Use Microdata Series, International: Version 6.2 [Machine-readable database]. University of Minnesota, Minneapolis

Clark R, Ramsbey T, Adler E (1991) Culture, gender and labor force participation: a cross-national study. Gend Soc 5(1):47-66

Desai RM, Olfsgard A, Yousef T (2009) The logic of the authoritarian bargain. Econ Polit 21(1):93-125

ELMPS (2006) Egypt Labor Market Panel Survey 2006. Economic Research Forum, Cairo, Egypt, (www.erfdataportal.com)

ESCWA (2012) Economic Policy in the ESCWA Region and its Impact on Employment. United Nations, New York

Fields GS (1975) Rural-urban migration, urban unemployment and underemployment, and job-search activity in LDCs. J Dev Econ 2(2):165-187 
Gallup (2012) Gallup World Poll. Gallup Inc, Washington D.C.

Harris J, Todaro M (1970) Migration, unemployment, and development: a two-sector analysis. Am Econ Rev 60 (1970):126-142

ILO (2013) Global Employment Trends for Youth 2013. International Labour Office, Geneva

ILO (2011) Key Indicators of the Labour Market (KILM), 7th edn. International Labour Office, Geneva

JLMPS (2010) Jordan Labor Market Panel Survey 2010. Economic Research Forum, Cairo, Egypt, (http://www.erforg.eg/ cms.php?id=research_details\&research_id=197)

Karshenas M, Moghadam VM (2001) Female labor force participation and economic adjustment in the MENA region. Res Middle East Econ 4:51-74

Lowi M (2009) Oil Wealth and the Poverty of Politics. Cambridge University Press, Cambridge, U.K.

Malik A, Awadallah B (2013) The economics of the Arab Spring. World Dev 45(May):296-313

Miles R (2002) Employment and unemployment in Jordan: the importance of the gender system. World Dev 30(3):413-427

Robinson J, Torvik R, Verdier T (2006) Political foundations of the resource curse. J Dev Econ 79(2):447-468

Ross M (2008) Oil, Islam, and women. Am Polit Sci Rev 102:107-123

Said M (2013) Wage Formation and Earnings Inequality in the Jordanian Labor Market. In: Assaad R (ed) The Jordanian Labor Market in the New Millennium. Oxford University Press (forthcoming), Oxford

Said M (2009) The Fall and Rise of Earnings and Inequality in Egypt: New Evidence from the Egypt Labor Market Panel survey 2006. In: Assaad R (ed) The Egyptian Labor Market Revisited. American University in Cairo Press, Cairo, pp 53-85

Said M (2001) In: Salehi-Isfahani D (ed) Labor and Human Capital in the Middle East: Studies of Markets and Household Behavior. Ithaca Press, Reading, U.K, pp 91-145

Salehi-Isfahani D (2012) Education, jobs, and equity in the Middle East and North Africa. Comp Econ Stud 54:843-861

Shaban R, Assaad R, Al-Qudsi S (2001) Employment experience in the Middle East and North Africa. In: Salehi-Isfahani D (ed) Labor and Human Capital in the Middle East: Studies of Markets and Household Behavior. Ithaca Press, Reading, U.K, pp 21-66

Sidani Y (2005) Women, work, and Islam in Arab societies. Women Manag Rev 20(7):498-512

Soliman S (2011) The Autumn of Dictatorship: Fiscal Crisis and Political Change in Egypt under Mubarak. Stanford University Press, Stanford

Spierings N, Smits J, Verloo N (2009) On the compatibility of Islam and gender equality: effects of modernization, state Islamization, and democracy on women's labor market participation in 45 Muslim countries. Soc Indic Res 90:503-522

Muliss I, Martin M, Foy P (2008) TIMSS 2007 International Mathematics Report: Findings from IEA's Trends in International Mathematics and Science Study at the Fourth and Eighth Grades. TIMSS \& PIRLS International Study Center, Lynn School of Education, Boston College, Chestnut Hill, MA

World Bank (No Date) Wage Bill and Pay Compression Summary Note. World Bank, Washington D.C

World Bank (2004a) Unlocking the Employment Potential in the Middle East and North Africa: Toward a New Social Contract. World Bank, Washington D.C

World Bank (2004b) Gender and Development in the Middle East and North Africa: Women in the Public Sphere. World Bank, Washington D.C

World Bank (2013a) Jobs for Shared Prosperity: Time for Action in the Middle East and North Africa. World Bank, Washington D.C

World Bank (2013b) Opening Doors: Gender Equality and Development in the Middle East and North Africa. World Bank, Washington D.C

World Bank (2013c) World Development Indicators Data Set. The World Bank, Washington D.C

10.1186/2193-9020-3-6

Cite this article as: Assaad: Making sense of Arab labor markets: the enduring legacy of dualism. IZA Journal of Labor \& Development 2014, 3:6

\section{Submit your manuscript to a SpringerOpen ${ }^{\circ}$ journal and benefit from:}

- Convenient online submission

- Rigorous peer review

- Immediate publication on acceptance

- Open access: articles freely available online

- High visibility within the field

Retaining the copyright to your article

Submit your next manuscript at $\boldsymbol{\nabla}$ springeropen.com 